Atmos. Chem. Phys. Discuss., 10, 28183-28230, 2010

www.atmos-chem-phys-discuss.net/10/28183/2010/

doi:10.5194/acpd-10-28183-2010

(c) Author(s) 2010. CC Attribution 3.0 License.

\title{
The impact of different nitrous acid sources in the air quality levels of the Iberian Peninsula
}

M. Gonçalves ${ }^{1,2}$, D. Dabdub ${ }^{3}$, W. L. Chang ${ }^{3}$, F. Saiz ${ }^{3}$, O. Jorba ${ }^{2}$, and J. M. Baldasano ${ }^{1,2}$

${ }^{1}$ Environmental Modeling Laboratory, Projects Department, Technical University of Catalonia, Barcelona, Spain

${ }^{2}$ Earth Sciences Department, Barcelona Supercomputing Center, Barcelona, Spain

${ }^{3}$ Department of Mechanical and Aerospace Engineering, University of California, Irvine, Irvine, California, USA

Received: 21 October 2010 - Accepted: 5 November 2010 - Published: 17 November 2010 Correspondence to: M. Gonçalves (maria.goncalves@upc.edu)

Published by Copernicus Publications on behalf of the European Geosciences Union.
Different nitrous acid sources in the air quality levels

M. Gonçalves et al.

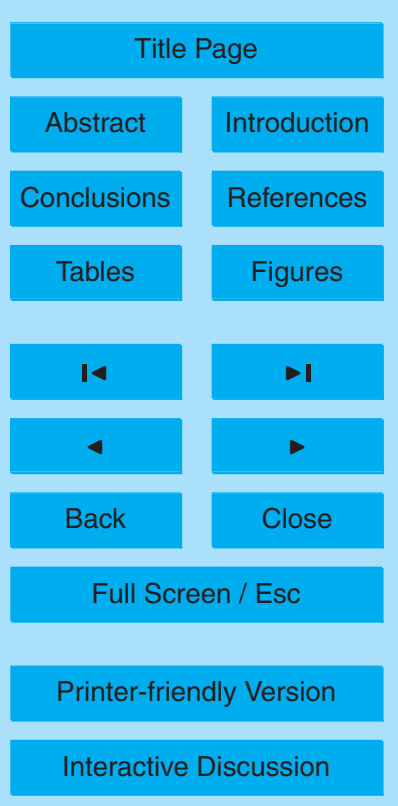




\section{Abstract}

Hydroxyl radical $(\mathrm{OH})$ is a primary oxidant in the atmosphere and affects both gasphase pollutants and particulate matter levels. Nitrous acid (HONO) acts as an important source of $\mathrm{OH}$ in the urban atmosphere. Therefore it is important to account accu5 rately for HONO sources within air quality models in order to predict air pollution dynamics. HONO observations in urban areas are characterized by high concentrations at night and low concentrations around midday. Existing gas-phase chemical mechanisms do not reproduce the observed HONO levels, suggesting a lack of sources, such as direct emissions or heterogeneous reactions. Specific HONO emission rates, heterogeneous chemical mechanisms leading to its formation and related kinetics are still unclear. Therefore, most air quality models consider exclusively gas-phase chemistry related to HONO. This work applies the WRF-ARW/HERMES/CMAQ modeling system to quantify the effect of the addition of HONO sources in the predictability of HONO profiles, and its subsequent effect on secondary pollutants formation (mainly $\mathrm{O}_{3}$ and

$15 \mathrm{PM}_{2.5}$ ). The modeling episode is based on a 2004 severe summertime pollution event in the Iberian Peninsula, using high resolution of $4 \times 4 \mathrm{~km}^{2}$. Two different parameterizations for emissions and the hydrolysis of $\mathrm{NO}_{2}$ on wet surfaces are added as HONO sources in the atmosphere. Emissions have the largest impact on HONO levels, especially in urban areas, where they can contribute from $66 \%$ to $94 \%$ to the HONO peak concentration. Additionally, in urban environments, $\mathrm{NO}_{2}$ hydrolysis on building and vegetation surfaces contributes up to $30 \%$ to the HONO peak. Both, the available surface area and the relative humidity must be included as parameters affecting the $\mathrm{NO}_{2}$ hydrolysis kinetics. As a result, $\mathrm{NO}_{2}$ hydrolysis is negligible on aerosol surfaces, due to the small surface area available for reaction, and it is more effective in producing HONO below high relative humidity conditions. The addition of HONO sources affects the concentration of secondary pollutants. In particular, major changes are produced in the early morning, due to the higher $\mathrm{OH}$ release via HONO photolysis. Significant changes in $\mathrm{PM}_{2.5}$ concentrations are predicted, that can be $16 \%\left(2.6 \mu \mathrm{g} \mathrm{m}^{-3}\right)$ higher in

\section{Different nitrous acid sources in the air quality levels}

M. Gonçalves et al.

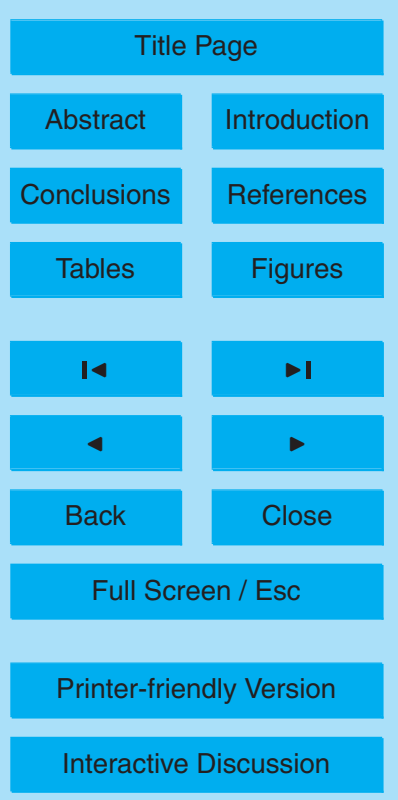


the new scenarios. When accounting for HONO sources, nitrate levels increase especially in urban areas and sulfates in areas downwind from conventional power plants in the Iberian Peninsula. Also, $\mathrm{O}_{3}$ peak concentrations are slightly affected (from 0.7 to $4 \mathrm{ppb}, 1 \%$ to $4.5 \%$ ). The improvement of the HONO sources representation within air 5 quality models produces changes in $\mathrm{O}_{3}$ peak predictions and significantly affects the reaction pathways leading to aerosols formation. Therefore, HONO sources other than gas-phase chemistry should be accurately included within modeling frameworks.

\section{Introduction}

Nitrous acid (HONO) is one of the most important sources of hydroxyl radical $(\mathrm{OH})$ 10 (Calvert and Yarwood, 1994; Elshorbany et al., 2009), a primary oxidant in the troposphere that alters both gas-phase pollutants and aerosol levels. One of the sources of $\mathrm{OH}$ is the photolysis of $\mathrm{HONO}$ :

$\mathrm{HONO}+h v \stackrel{290 \mathrm{~nm}<\lambda<400 \mathrm{~nm}}{\longrightarrow} \mathrm{NO}+\mathrm{OH}$.

Reaction (R1) is especially important in urban areas (Platt et al., 1980; Lammel and 15 Cape, 1996; Alicke et al., 2002, 2003). Therefore, it is crucial to represent HONO sources and sinks adequately within air quality models in order to predict accurately air pollution levels.

The homogeneous gas phase chemistry leading to HONO formation is well-known (Platt et al., 1980), but its specific contribution to atmospheric HONO levels is relatively low (Svensson et al., 1987; Winer and Bierman, 1994; Moussiopoulos et al., 2000; Kurtenbach et al., 2001). During daytime, HONO is formed through the reaction of nitrogen monoxide (NO) with $\mathrm{OH}$,

$\mathrm{NO}+\mathrm{OH} \stackrel{\mathrm{M}}{\longrightarrow} \mathrm{HONO}$,

where $M$ is the third body required to stabilize the product. Reaction (R2) is not consid-

ered an important net source of nitrous acid, however, due to the more efficient reverse
10, 28183-28230, 2010

\section{Different nitrous acid sources in the air quality levels}

M. Gonçalves et al.

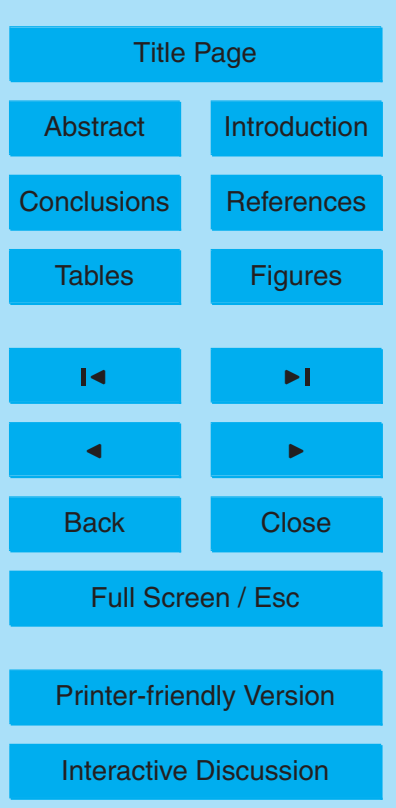

Interactive Discussion 
photolytic reaction described by Reaction (R1). Another gas-phase source of HONO is the reaction of nitrogen oxides $\left(\mathrm{NO}_{\mathrm{x}}\right)$ with water vapor,

$\mathrm{NO}+\mathrm{NO}_{2}+\mathrm{H}_{2} \mathrm{O} \rightarrow 2 \mathrm{HONO}$,

but since its slow reaction rate with kinetic constant $\left(\mathrm{cm}^{6}\right.$ molec $\left.{ }^{-2} \mathrm{~s}^{-1}\right)$ roughly 20 or5 ders of magnitude less than its faster opposite reaction,

$\mathrm{HONO}+\mathrm{HONO} \rightarrow \mathrm{NO}+\mathrm{NO}_{2}+\mathrm{H}_{2} \mathrm{O}$,

Reaction (R3) is also considered a minor contributor to the HONO daily budget (Kaisser and $\mathrm{Wu}, 1977$; Jeffries et al., 2002). The reaction between $\mathrm{HONO}$ and $\mathrm{OH}$,

$\mathrm{HONO}+\mathrm{OH} \rightarrow \mathrm{NO}_{2}+\mathrm{H}_{2} \mathrm{O}$

10 is also a sink of HONO, but it is less prominent than the photolytic pathway (Reaction R1).

Homogeneous chemistry alone fails to capture the observed HONO buildup in the urban atmosphere during nighttime, as previous measurement campaigns suggest (Calvert et al., 1994, and references therein). Thus, the contribution of other sources of HONO, such as emissions or heterogeneous chemistry, must account for HONO levels in the atmosphere that are currently not captured by modeling studies.

Combustion processes as a source of HONO emissions were widely recognized in the early nineties (Calvert et al., 1990; Winer and Biermann, 1994), and on-road transport is the sector with the largest contribution, especially in urban areas. Despite its importance, the development of comprehensive HONO emission factors for modeling purposes has been rather slow due to the lack of extensive measurements. In the recent decades, several studies (e.g. Kirschtetter et al., 1996; Kurtenbach et al., 2001) explored HONO emissions from on-road traffic, yet high uncertainties regarding HONO emission factors applicable to emission models still remain.

25 Heterogeneous chemistry is another HONO source in the atmosphere with high uncertainties, where the specific chemical mechanisms and reaction kinetics still remain
10, 28183-28230, 2010

\section{Different nitrous acid sources in the air quality levels}

M. Gonçalves et al.

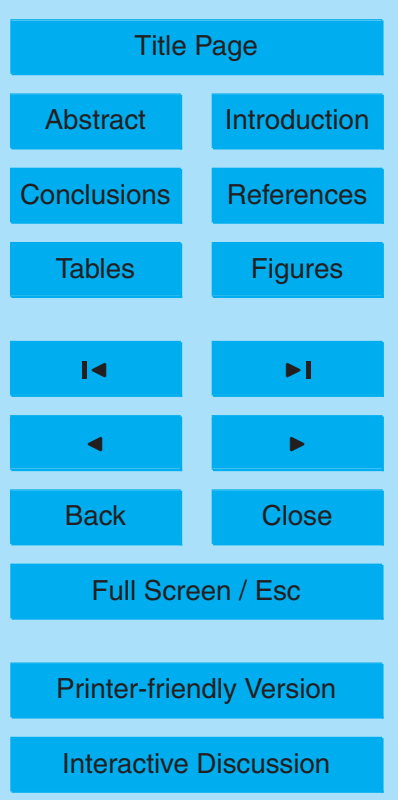

Interactive Discussion 
unclear. A proposed pathway for HONO formation in the atmosphere is the hydrolysis of $\mathrm{NO}_{2}$ on wet surfaces (Kleffmann et al., 1998; Kurtenbach et al., 2001; FinlaysonPitts, 2003; Stutz et al., 2004):

$2 \mathrm{NO}_{2}+\mathrm{H}_{2} \mathrm{O} \rightarrow \mathrm{HONO}+\mathrm{HNO}_{3}$

5 Laboratory studies indicate that the kinetics of Reaction (R6) is likely to be first order in $\mathrm{NO}_{2}$ (Kleffmann et al., 1998; Fynlayson-Pitts et al., 2003) and dependent on relative humidity (Stutz et al., 2004).

The oxidation of $\mathrm{NO}_{2}$ adsorbed on aerosol surfaces could also lead to nitrous acid production (Ammann et al., 1998):

$10 \quad \mathrm{NO}_{2}+$ reduced aerosol $\rightarrow \mathrm{HONO}+$ oxidized aerosol

Although the kinetics of Reaction (R7) is favored over Reaction (R6) (Ziemba et al., 2009), the fast deactivation of the aerosol surface, and the smaller available surface area compared to buildings or vegetation surfaces, raise the question of the relative importance of Reaction (R7) to the atmospheric HONO budget (Sarwar et al., 2008).

15 Recent findings suggest that the importance of Reaction (R7) would be its role on the detected HONO levels in diesel vehicles exhaust (Gutzwiller et al., 2002).

In addition, Ziemba et al. (2009) proposed the heterogeneous conversion of nitric acid $\left(\mathrm{HNO}_{3}\right)$ to $\mathrm{HONO}$ on primary organic aerosols as a potential pathway for the HONO production in the atmosphere during early morning. Other modeling studies have been performed to characterize different HONO sources and quantify their impact on air quality (Moussiopoulos et al., 2000; Sarwar et al., 2008; Wennberg and Dabdub, 2008), but predicted levels of HONO have consistently been shown to be distinctively lower than values from observations. Hence, the specifics of the sources, chemical mechanisms and corresponding kinetics associated with HONO still require further exploration.

WRF-ARW/HERMES/CMAQ (Baldasano et al., 2008b; Baldasano et al., 2010; Pay et al., 2010) modeling system to analyze the contribution of different HONO sources to

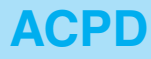

10, 28183-28230, 2010

\section{Different nitrous acid sources in the air quality levels}

M. Gonçalves et al.

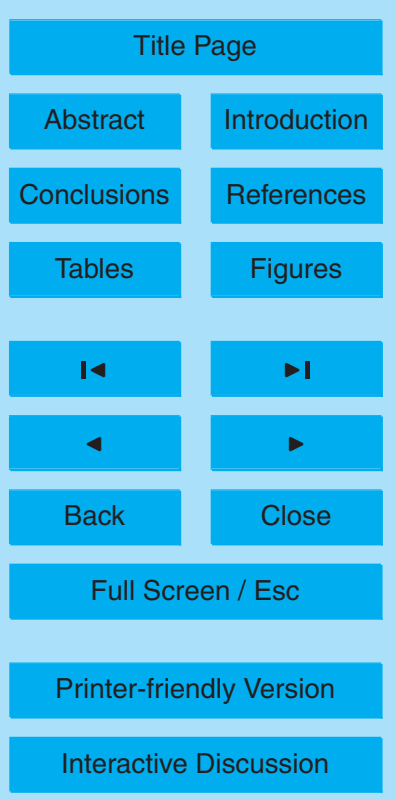

Interactive Discussion 
HONO levels and the subsequent effect on secondary pollutants in the Iberian Peninsula during a severe summertime air pollution event in 2004. Two different parameterizations for HONO emissions which cover the range of the current state-of-the-art measurements are considered, and the details are provided in Sect. 2.2. In the following 5 section, $\mathrm{HONO}$ production through $\mathrm{NO}_{2}$ hydrolysis on surfaces is also examined. For the first time, the dependence of the hydrolysis kinetics on relative humidity is analyzed and compared to the current parameterization included in CMAQv4.7, which depends exclusively on the available surface area. Finally, the contribution of each emission and heterogeneous source to atmospheric HONO dynamics within the Iberian Penin10 sula is quantified. Section 3 discusses the effects of $\mathrm{HONO}$ sources on $\mathrm{O}_{3}$ as well as $\mathrm{PM}_{2.5}$ levels and composition. This work focuses on ozone and fine particulate matter due to their significance as main threats to human health and the high levels of these pollutants observed in the Iberian Peninsula (Jiménez et al., 2006; EEA, 2009).

\section{Methods}

\section{$15 \quad 2.1$ Modeling framework}

The Advanced Research Weather Research and Forecasting (WRF-ARW) Model v3.0.1.1 (Michalakes et al., 2004; Skamarock and Klemp, 2008) provides the necessary meteorological inputs for the air quality simulations. The High Elective Resolution Modeling System (HERMES; Baldasano et al, 2008a) is used to estimate emissions of gas-phase and aerosol pollutants in the Iberian Peninsula. The third generation Models-3 Community Mesoscale Air Quality (CMAQ) Modeling System v4.7 (Byun and Ching, 1999; Foley et al., 2010) provides the evolution of the air quality levels, including tropospheric $\mathrm{O}_{3}$ and fine particulate matter. In particular, gas phase chemistry is represented by the Carbon Bond 5 (CB05) chemical mechanism (Yarwood et al., 2005). Aerosols chemistry and processes are treated through the AERO5 module, which includes sea salt emissions (Gong, 2003; Zhang et al., 2005) and a recently
ACPD

10, 28183-28230, 2010

\section{Different nitrous acid sources in the air quality levels}

M. Gonçalves et al.

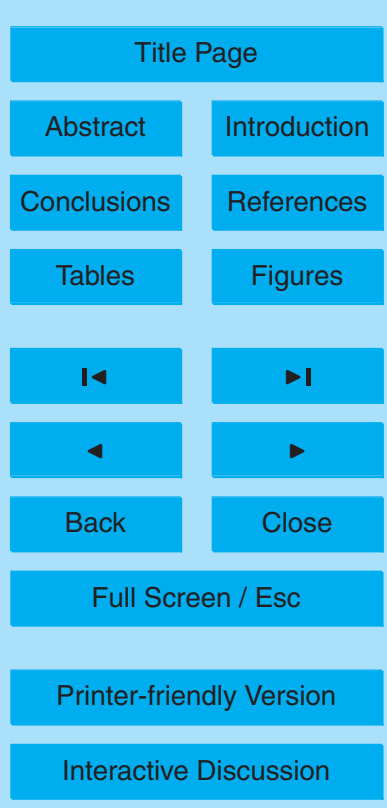


updated secondary organic aerosols treatment (Edney et al., 2007). A modal approach using three lognormal modes (Aitken, accumulation and coarse) describes the aerosol size distribution (Binkowski and Roselle, 2003; Byun and Schere, 2006). Intermodal and intramodal coagulation processes, condensation and evaporation and cloud pro5 cesses are represented.

The WRF-ARW/HERMES/CMAQ modeling system has been used extensively to assess the air quality levels in the Iberian Peninsula, both in the hindcast and forecast modes (e.g. Baldasano et al., 2008b; Pay et al., 2010). The capabilities of this framework to predict air pollutant levels have been analyzed in depth. Model performance fits 10 within the recommendations of the European Union (Dir. 2008/50/EC) and the US-EPA (US-EPA, 1991, 2007) (Jiménez-Guerrero et al., 2006, 2008, Baldasano et al., 2008b, Piot et al., 2009; Pay et al., 2009, 2010; Baldasano et al., 2010)

The model is applied to the Iberian Peninsula (domain D2 in Fig. 1) with $4 \mathrm{~km} \times 4 \mathrm{~km}$ horizontal resolution and 15 sigma vertical layers up to the top of the atmosphere, 15 set at $50 \mathrm{hPa}$. Initial conditions are provided by means of a $24 \mathrm{~h}$ spin-up. Boundary conditions are obtained from a coarser simulation covering the European region (D1, $12 \mathrm{~km} \times 12 \mathrm{~km}$ horizontal resolution, 15 vertical sigma layers; Fig. 1). After a thorough analysis of $\mathrm{O}_{3}, \mathrm{NO}_{2}$ and $\mathrm{PM}_{2.5}$ observations in Spain for the year 2004 (provided by the Spanish Air Quality Surveillance, CSIC and EMEP networks), 18 June 2004 is selected as the test episode for this study. The selected episode is representative of a severe summertime air pollution event not influenced by Saharan dust outbreaks, which is a requisite imposed in order to avoid the masking of secondary particulate matter formation by high dust concentrations.

\subsection{Nitrous acid emissions}

25 Anthropogenic nitrogen oxides $\left(\mathrm{NO}_{\mathrm{x}}\right)$ emissions are mainly derived from combustion processes, such as those related to motor vehicles, aircrafts and ships traffic, power generation plants, and residential and industrial applications. Experimental studies show that, in addition to $\mathrm{NO}_{\mathrm{x}}$, $\mathrm{HONO}$ is released from traffic exhaust (Kurtenbach et

\section{Different nitrous acid sources in the air quality levels}

M. Gonçalves et al.

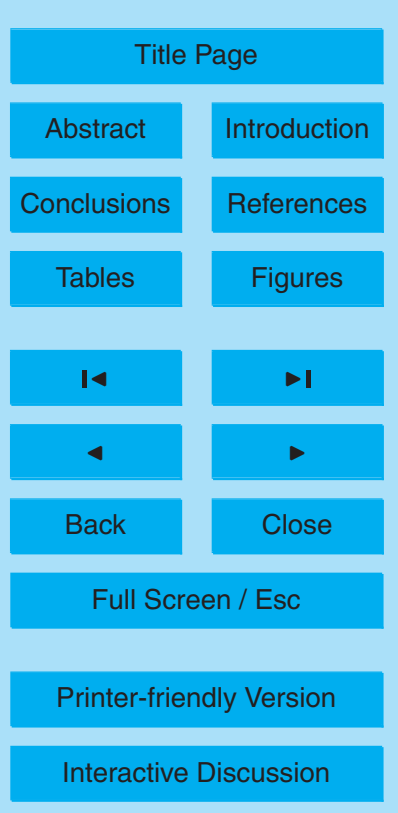


al., 2001). However, the latest guidelines for the estimation of emissions of the European Environmental Agency (EEA/EMEP-CORINAIR, 2009) and the speciation profiles provided by the US Environmental Protection Agency (US-EPA, 2008) do not consider on-road traffic as a potential HONO source.

5 Early studies concerning HONO speciation for anthropogenic sources recommended a $2.0 \% \mathrm{HONO} / \mathrm{NO}_{x}$ ratio for the emission estimations in order to capture ambient measurement levels (Harley, 1996). More recently, studies using different vehicles and engine tests have shown that $\mathrm{HONO}$ to $\mathrm{NO}_{\mathrm{x}}$ emission ratios range from $0.01 \%$ to $1.8 \%$ (Kurtenbach et al., 2001; Jenkin et al., 2008), depending on the vehicle type, the fuel 10 type and the oxygen content. Generally, diesel vehicles under rich operation conditions lead to higher $\mathrm{HONO} / \mathrm{NO}_{\mathrm{x}}$ ratios than gasoline fuelled vehicles under lean operation conditions (Kurtenbach et al., 2001). Kirschtetter et al. (1996) measured a HONO/NO ratio of $0.29 \%( \pm 0.05 \%)$ in a tunnel study conducted in California, where more than $99 \%$ of the vehicle fleet are gasoline fuelled vehicles. Kurtenbach et al. (2001) sam15 pled a $0.8 \%( \pm 1.0 \%)$ ratio in Germany, where the average vehicle fleet composition included around $75 \%$ of gasoline fuelled cars. The latter (Kurtenbach et al., 2001) results have already been adopted by several modeling communities, such as the Models-3 Community in the US and the CHIMERE community in France (Sarwar et al., 2008; INERIS, 2009). The Spanish vehicle fleet in 2004, on the other hand, is composed of $52 \%$ of gasoline vehicles and $48 \%$ of diesel fuelled vehicles (DGT, 2010), so a higher $\mathrm{HONO} / \mathrm{NO}_{\mathrm{x}}$ ratio from on-road traffic is expected.

HERMES-2004 for this study follows the EEA/EMEP-CORINAIR methodologies for estimating emissions (EEA/EMEP-CORINAIR, 2009) and applies the US-EPA (2003) speciation profiles for $\mathrm{NO}_{\mathrm{x}}$. Currently, the recommendation from the US-EPA allocates $95 \%$ of total $\mathrm{NO}_{x}$ as $\mathrm{NO}$ and $5 \%$ as $\mathrm{NO}_{2}$ for on-road traffic emissions, and $90 \%$ as $\mathrm{NO}$ and $10 \%$ as $\mathrm{NO}_{2}$ for all other sources.

In order to include HONO emissions two different emissions parameterizations are examined in this work: (1) $0.8 \%$ of $\mathrm{NO}_{x}$ from mobile sources, the most widely accepted $\mathrm{HONO} / \mathrm{NO}_{\mathrm{x}}$ emission ratio; (2) $2 \%$ of total $\mathrm{NO}_{\mathrm{x}}$ for all the anthropogenic sources, an

\section{Different nitrous acid sources in the air quality levels}

M. Gonçalves et al.

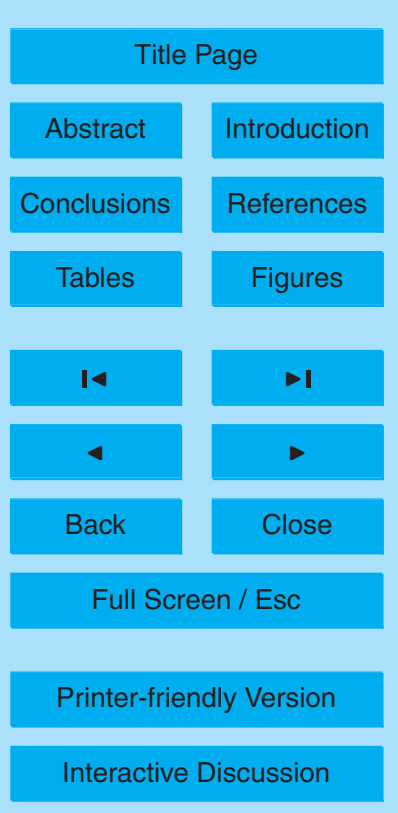


upper limit based on the early studies by Harley (1996) that is currently used by the California Air Resources Board.

\subsection{Gas phase chemical mechanisms for air quality models}

The most widely used gas-phase chemical mechanisms within air quality models share 5 a common representation of the homogeneous chemistry concerning HONO. Table 1 summarizes HONO chemistry in Carbon Bond IV - CBIV (Gery et al., 1988), Carbon Bond 5 - CB05 (Yarwood et al., 2005), SAPRC-99 (Carter, 2000), SAPRC-07 (Carter, 2010), Caltech Atmospheric Chemistry Mechanism - CACM (Griffin et al., 2002) and MELCHIOR2 (Lattuati, 1997; Derognat et al., 2003). They all agree in the two main 10 reactions leading to HONO consumption with similar kinetics: the HONO photolysis (Reaction R1) and the reaction between $\mathrm{HONO}$ and $\mathrm{OH}$ (Reaction R5). Most mechanisms also include the reaction of $\mathrm{NO}$ with $\mathrm{OH}$ (Reaction R2) to form $\mathrm{HONO}$ with the same kinetics, except for CB-IV, which dates from 1988. In SAPRC and MELCHIOR mechanisms, Reaction (R2) is the unique homogeneous HONO source, while CB-IV, CB05 and CACM also include the reaction pathway involving $\mathrm{NO}_{2}$ and $\mathrm{H}_{2} \mathrm{O}$ (Reaction R3). However, as aforementioned, the net HONO formation via Reaction (R3) is expected to be low due to the faster inverse Reaction (R4). This work applies the CB05 chemical mechanism for the gas-phase chemistry treatment. HONO formation depends upon the $\mathrm{NO}_{\mathrm{x}}$ concentration and the availability of the third body (M, being $\mathrm{N}_{2}$ or $\mathrm{O}_{2}$ ). During daytime, HONO photolysis acts as an efficient HONO sink and HONO reaction with available $\mathrm{OH}$ to produce $\mathrm{NO}_{x}$ and $\mathrm{H}_{2} \mathrm{O}$ constitute the main gas-phase sinks at nighttime.

\subsection{Heterogeneous chemistry on surfaces}

Modeling studies have shown that the sum of direct emission and homogeneous production of HONO is not able to reproduce the observed atmospheric HONO levels (Moussiopoulos et al., 2000; Vogel et al., 2003), especially during early morning and
ACPD

10, 28183-28230, 2010

Different nitrous acid sources in the air quality levels

M. Gonçalves et al.

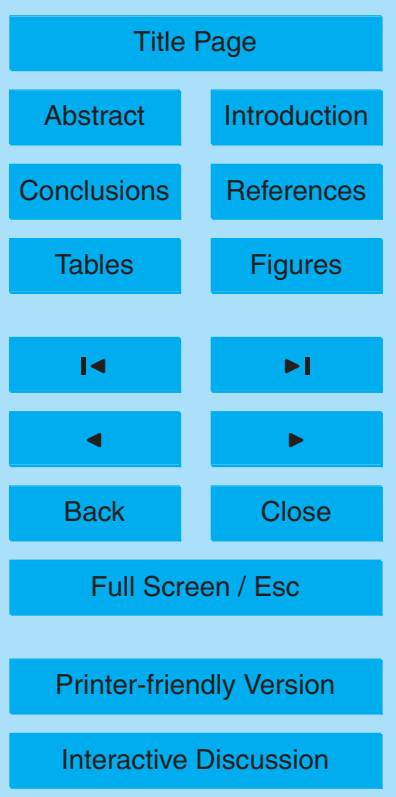


nighttime peaks. Evidence of heterogeneous HONO formation has been confirmed through both tunnel observations (Kurtenbach et al, 2001; Kirschtetter et al., 1996) and chamber experiments (Syomin and Finlayson-Pitts, 2003; Finlayson-Pitts et al., 2003; Stutz et al., 2004), although the specific chemical mechanisms and kinetics are 5 still under discussion in the atmospheric chemistry community.

This work focuses in the $\mathrm{NO}_{2}$ hydrolysis on ground, buildings and vegetation surfaces (Reaction R6), which is believed to be a major contributor to HONO formation in the atmosphere (Finlayson-Pitts et al., 2003). The kinetics of HONO production through R6 is pseudo-first order in $\mathrm{NO}_{2}$ (Kleffmann et al., 1998; Finlayson-Pitts et al., 2003), and it 10 exhibits a strong dependence on relative humidity (Stutz et al., 2004). While previous modeling studies have considered R6 on ground surfaces (Sarwar et al., 2008), the role of relative humidity was not considered.

This work evaluates the effects of two different kinetic parameterizations for the $\mathrm{NO}_{2}$ hydrolysis. First, the existing approach included in the CMAQv4.7 model is applied 15 (Sarwar et al., 2008). It uses a kinetic constant, $k_{1}$ in [(ppm HONO) (ppm NO$\left.)^{-1} \mathrm{~s}^{-1}\right]$, based on the work of Kurtenbach et al. (2001),

$k_{1}=3.0 \times 10^{-3}\left(\frac{S}{V}\right)$

where $S$ represents the available surface area within a given volume, $V$.

The types of surfaces considered for the reaction are:

1. Vegetation surfaces, where

$$
\frac{S}{V}=\frac{2 \mathrm{LAl}}{\text { surface layer height }} \text {, }
$$

with LAI being the Leaf Area Index.

2. Building surfaces, which are parameterized as a function of the percentage of urban area in each cell of the domain, and $0.2 \mathrm{~m}^{-1}$ is used for the cell with $100 \%$ of urban area.

\section{Different nitrous acid sources in the air quality levels}

M. Gonçalves et al.

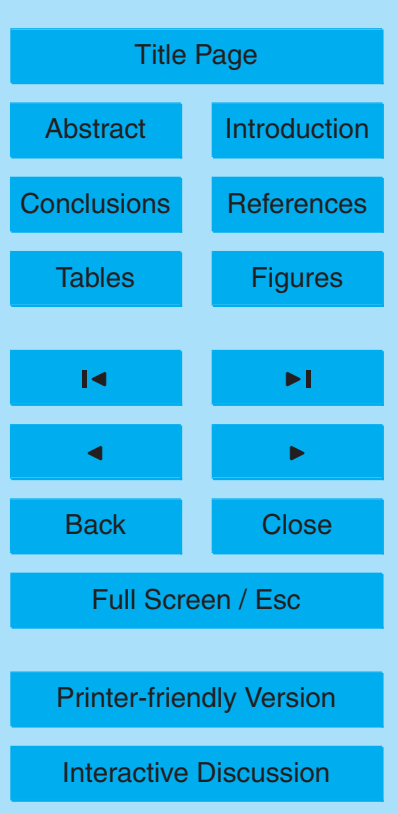

Interactive Discussion 
3. Aerosol surfaces, where the surface to volume ratio is computed within the AERO5 module in CMAQv4.7.

Second, a new expression is derived using an averaged HONO production rate of previous chamber studies summarized in Finlayson-Pitts et al. (2003) for Reaction (R6), 50.22 (ppb HONO) (ppm NO$)^{-1} \mathrm{~min}^{-1}$. This reaction is known to be pseudo-first order in $\mathrm{NO}_{2}$, therefore, the HONO production can be expressed as

$$
\frac{d[\mathrm{HONO}]}{d t}=k_{2}\left[\mathrm{NO}_{2}\right] \text {. }
$$

In addition, the kinetic constant is known to be dependent on the surface area to volume ratio available for the reaction and the relative humidity, where the relationship 10 is approximately linear between $10 \%$ and $90 \%$ relative humidity (Finlayson-Pitts et al., 2003). Therefore, the kinetic constant, $k_{2}\left[(p p m ~ H O N O)\left(p p m ~ N_{2}\right)^{-1} s^{-1}\right]$, in Eq. (3) can be expressed as

$k_{2}=A \cdot v_{\mathrm{dep}_{\mathrm{NO}_{2}}} \mathrm{RH} \cdot\left(\frac{S}{V}\right)$,

where $A$ is the correction factor, $v_{\mathrm{dep}_{\mathrm{NO}_{2}}}$ is the deposition velocity of $\mathrm{NO}_{2}\left(\mathrm{~m} \mathrm{~s}^{-1}\right), \mathrm{RH}$ 15 is the relative humidity $(\%)$ and $S$ is the surface area $\left(\mathrm{m}^{2}\right)$ within a given volume, $V$ $\left(\mathrm{m}^{3}\right)$. Taking into account the chamber conditions at the $\mathrm{RH}$ of $50 \%$ and the $S / V$ ratio of $3.4 \mathrm{~m}^{-1}$, as reported by Finlayson-Pitts et al. (2003), the expression for $k_{2}$ [ppm $\mathrm{HONO}$ ppm $\mathrm{NO}_{2} \mathrm{~s}^{-1}$ ] can be rewritten as

$k_{2}=9.7 \times 10^{-5} v_{\mathrm{dep}_{\mathrm{NO}_{2}}} \mathrm{RH}\left(\frac{S}{V}\right)$.

20 The parameterizations for the $S / V$ ratio follow the recommendations from Sarwar et al. (2008) described above. For the Iberian Peninsula, the surface area of vegetation

Different nitrous acid sources in the air quality levels

M. Gonçalves et al.

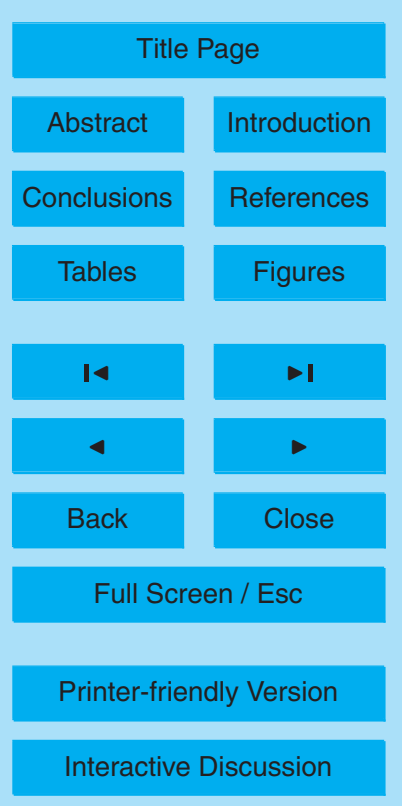

Interactive Discussion 
is estimated as a function of the Leaf Area Index (LAI), which is obtained from the MODIS TERRA MOD15A2 dataset provided by the Climate and Vegetation Research Group (Department of geography, Boston University, http://cybele.bu.edu/modismisr/ index.html; Ganguly et al., 2008) (Fig. 2a). The monthly averaged values at $4 \mathrm{~km}$ 5 resolution are adapted to the Iberian Peninsula grid. The percentage of urban area necessary for estimating the buildings surface area is estimated using the CORINE Land Cover Database (CORINE LCD; CLC, 2000). The CORINE LCD provides a high resolution $(100 \mathrm{~m} \times 100 \mathrm{~m})$ definition of land uses in the Iberian Peninsula, distributed in 44 different categories. The percentage of urban area in each grid cell of the domain

$10(4 \mathrm{~km} \times 4 \mathrm{~km})$ is estimated by assuming the land stretches of CORINE LCD categorized as continuous urban fabric (Fig. 2b).

The potential oxidation of $\mathrm{NO}_{2}$ in reduced aerosol surfaces (Reaction R7) is not likely to be important in the troposphere, as the aerosol surfaces are subjected to a rapid deactivation; therefore, it is not included within the tested HONO sources in this 15 work. Similarly, the hydrolysis of $\mathrm{HNO}_{3}$ on aerosol surfaces proposed by Ziemba et al. (2009) is not considered in this work due to the lack of specific mechanisms and kinetic data related to this process.

\subsection{Summary of the defined cases}

The combination of different emissions parameterizations and heterogeneous chem20 istry scenarios discussed above leads to the definition of seven study cases (Table 2), where each study case is analyzed against the base case (BASENA) that takes into account neither HONO emissions nor heterogeneous formation sources. The BASENA case is defined in order to provide a reference of the current behavior of air quality models which do not consider HONO sources other than gas-phase chemistry. The BASE 25 and BASENA cases differ exclusively in the activation of reaction (R6) on aerosol surfaces.

Cases EM08 and EM2 include emissions of HONO and can be described as "low $\mathrm{HONO}$ to $\mathrm{NO}_{\mathrm{x}}$ ratio case" and "high HONO to $\mathrm{NO}_{\mathrm{x}}$ ratio case", respectively. EM08 is

\section{Different nitrous acid sources in the air quality levels}

M. Gonçalves et al.

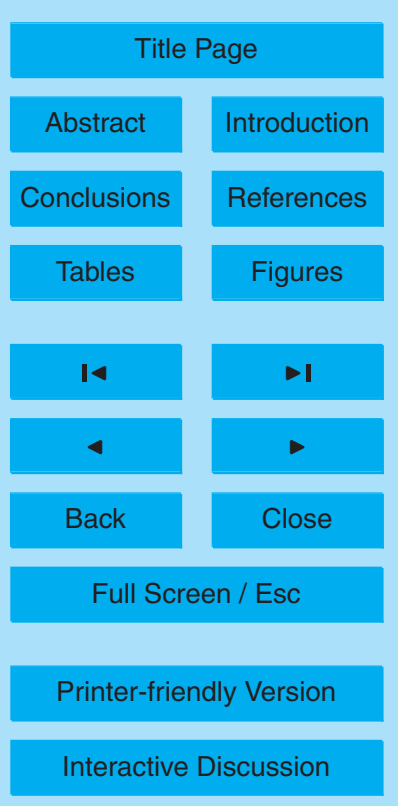


considered as the lower limit of a realistic scenario, since the vehicle fleet composition in the Iberian Peninsula has a large percentage of diesel vehicles. Case EM2, on the other hand, constitutes an upper limit, given that this $\mathrm{HONO} / \mathrm{NO}_{\mathrm{x}}$ ratio was initially proposed in order to reproduce the observed levels of HONO with emission sources 5 alone.

The main heterogeneous HONO formation process examined in this study is the $\mathrm{NO}_{2}$ hydrolysis on surfaces, and two kinetic parameterizations are considered. HC47 stands for the parameterization already included in CMAQv4.7, which depends upon the surface to volume ratio available for the reaction only (Eq. 1). The HCUCl kinetic expression, on the other hand, also considers the reaction dependence on relative humidity and the deposition velocity of $\mathrm{NO}_{2}$, in addition to the surface to volume ratio (Eq. 5). The HC47 parameterization is likely to result in faster HONO release on low relative humidity conditions, while the $\mathrm{HCUCl}$ parameterization would be comparable to the former when the relative humidity is high.

\section{Results and discussion}

\subsection{Air quality levels in the Iberian Peninsula during 18 June 2004}

The air quality in the Iberian Peninsula on 18 June 2004 is representative of a typical summer pollution episode, characterized by stagnant meteorological conditions. High temperatures, high solar radiation index and low wind speeds favor the formation and accumulation of secondary pollutants, such as $\mathrm{O}_{3}$. Particularly, 18 June exhibits the worst air quality in the Iberian Peninsula from anthropogenic origins during 2004.

The poorest air quality conditions occur in the urban plumes from the largest cities in the Iberian Peninsula. In particular, downwind areas from Madrid and Barcelona show concentrations of $\mathrm{O}_{3}$ above $100 \mathrm{ppb}$ from 14:00 to 16:00 UTC (Fig. 3a).

25 The highest $\mathrm{NO}_{2}$ and $\mathrm{PM}_{2.5}$ levels in the Iberian Peninsula are associated to onroad traffic emissions, showing peaks in urban areas during morning traffic rush hour

\section{ACPD}

10, 28183-28230, 2010

Different nitrous acid sources in the air quality levels

M. Gonçalves et al.

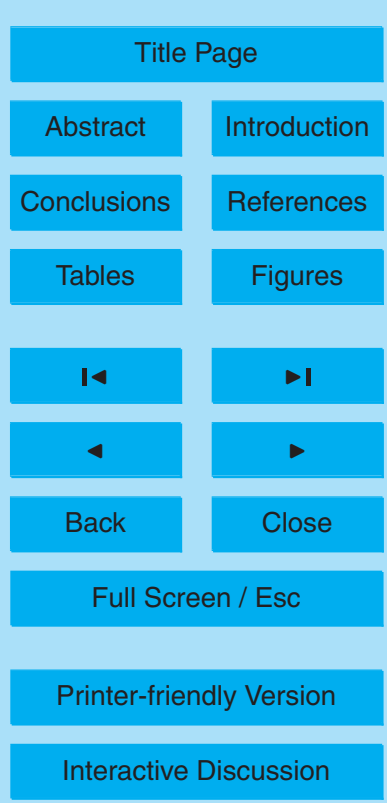


(07:00 UTC). $\mathrm{NO}_{2}$ concentrations up to $50 \mathrm{ppb}$ and $\mathrm{PM}_{2.5}$ up to $20-25 \mu \mathrm{g} \mathrm{m}^{-3}$ are predicted in the main Spanish and Portuguese urban areas (Fig. $3 b$ and c). Ships traffic through the strait of Gibraltar towards the Mediterranean Sea also contributes as an important source of $\mathrm{NO}_{x}$, and $\mathrm{NO}_{2}$ concentrations reach up to $30 \mathrm{ppb}$ over the ocean

5 (Fig. 3b). Additionally, in downwind areas from industrial sites in the northwestern and southwestern Iberian Peninsula, where there are a number of power plants and oil refineries, $\mathrm{NO}_{2}$ levels reach up to $40 \mathrm{ppb}$ (Fig. $3 \mathrm{~b}$ ) and $\mathrm{PM}_{2.5}$ peaks above $30 \mathrm{\mu g} \mathrm{m}^{-3}$ (Fig. 3d). The latter attributed both to primary $\mathrm{PM}_{2.5}$ emissions and secondary formation from the emitted precursors, mainly sulfur oxides. The $\mathrm{PM}_{2.5}$ levels are mostly composed of sulfates (specifically in downwind areas from large power plants) and nitrates (particularly in urban environments), with contributions up to $15 \mathrm{\mu g} \mathrm{m}^{-3}$.

Maximum levels of HONO reach up to $0.3 \mathrm{ppb}$ over the largest urban areas of Barcelona and Madrid for case BASENA (Fig. 3d) during the early morning (09:00 UTC). Concentrations of up to $0.05 \mathrm{ppb}$ before sunrise are well below the ref15 erence observed levels from other urban areas (Table 3). Historical measurements in the Los Angeles area showed HONO levels before sunrise up to $4.1 \mathrm{ppb}$ (Platt et al., 1980). Winer and Biermann (1994) reported the maximum observed HONO levels in urban areas so far, $15 \mathrm{ppb}$ at Long Beach before sunrise. More recently, up to $7.0 \mathrm{ppb}$ of HONO (10 min. average) were observed at 07:00 a.m. in Santiago de Chile 20 (Elshorbany et al., 2009), where the averaged maximum concentration during the measurement campaign was reported to be $3.7 \mathrm{ppb}$ at 08:00 h. Two different measurement campaigns carried out in summer and wintertime in New York City showed much lower values, with HONO peaks only up to 0.7 ppb before sunrise (Ren et al., 2003).

Urban HONO levels present wide variations depending on the specific emissions 25 and meteorological conditions. Nevertheless, observations follow a trend showing maximum HONO values before sunrise from $0.4 \mathrm{ppb}$ to $15 \mathrm{ppb}$. Daytime concentrations of HONO are low, falling sometimes below the detection limit (Table 3). Peak modeled HONO levels by WRF-ARW/HERMES/CMAQ for the Iberian Peninsula with gas-phase chemistry alone (BASENA) are on the order of one magnitude below the

\section{Different nitrous acid sources in the air quality levels}

M. Gonçalves et al.

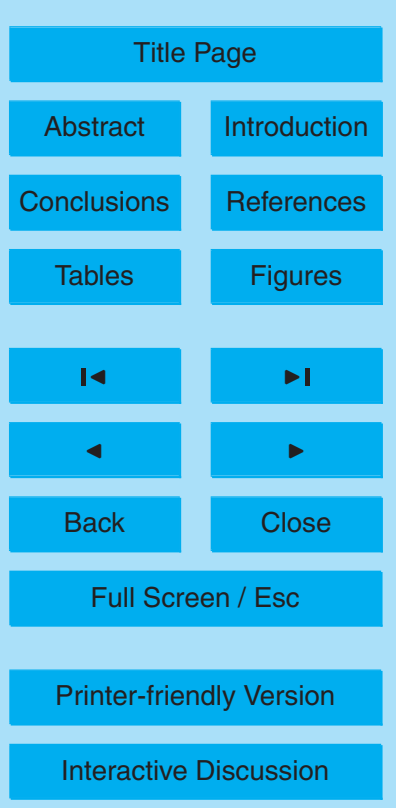


lowest observed values in urban areas (Table 3), corresponding to Ontario (Wentzell et al., 2010). These results are comparable to other modeling studies such as the WRFCHEM applied to the Mexico City area, where predicted HONO concentrations are also 10 times lower than observations when only gas-phase chemistry is considered (Li et 5 al., 2010). Moreover, the BASENA case produces a false peak in the early morning (Fig. 4) due to the lack of HONO sources to represent the HONO buildup during nighttime. This behavior has also been observed in previous works (Sarwar et al., 2008) that use CMAQv4.6 with the CB05 chemical mechanism. The false-peak behavior is likely to occur in other air quality models that only consider gas-phase chemistry as 10 well, since the most commonly used chemical mechanisms share the same basic reactions related to HONO gas-phase sources and sinks (Table 1). Therefore, additional sources must be included within air quality models in order to capture observed levels.

\subsection{Impact of the additional sources on HONO levels}

The introduction of HONO emissions in the model raises the overall HONO levels and 15 improves the predicted hourly profiles. Higher HONO levels are observed during nighttime and the peak occurrence is shifted from the early morning to just before sunrise, especially near the major $\mathrm{NO}_{x}$ sources (e.g. urban areas, see Fig. 4). HONO emitted as $0.8 \%$ of $\mathrm{NO}_{\mathrm{x}}$ from mobile sources (EM08) raises HONO peaks in urban areas during the morning rush hour as much as $0.5 \mathrm{ppb}$ with respect to the BASENA case. 20 Case EM2, when $\mathrm{HONO}$ emissions are included as $2 \%$ of the total $\mathrm{NO}_{\mathrm{x}}$ emissions, presents are more dramatic impact. Urban areas such as Madrid and Barcelona show an increase in HONO peak up to $1.4 \mathrm{ppb}$ with respect to the BASENA case. Predicted HONO peaks in urban environments fall within the range of observed values for other urban areas (Table 3) when including direct emissions. Specific measurements for 25 the Iberian Peninsula region are needed in order to quantify the deviation of model predictions from reality.

Activation of the heterogeneous reaction on aerosol surfaces, Reaction (R6), does not have a noticeable impact on HONO levels, mainly because the surface to volume

\section{Different nitrous acid sources in the air quality levels}

M. Gonçalves et al.

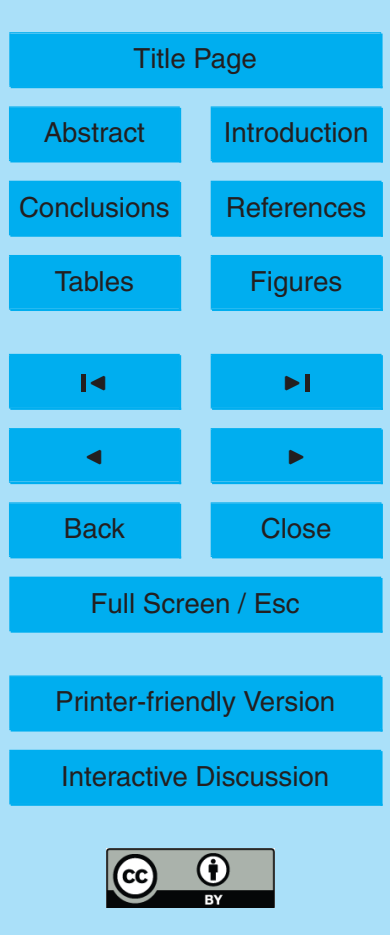


ratio on particles is low compared to ground surfaces. To put it into perspective, $S / V$ ratios for coarse fraction of aerosols for this simulation are on the order of $10^{-5} \mathrm{~m}^{-1}$, and $10^{-4} \mathrm{~m}^{-1}$ for the finest fractions (Aitken and Accumulation), as opposed to ratios on the order of $10^{-1}$ for the ground surfaces. From now on the BASE and BASENA 5 cases are considered as analogous, as the analysis of the specific impact in terms of secondary pollutants also shows none or negligible change in concentration.

In terms of $\mathrm{NO}_{2}$ hydrolysis on ground surfaces, the surface area available for the reactions is a fundamental factor affecting the kinetics. Therefore, the main effects of the HONO heterogeneous production are observed in those areas with large vegetation 10 coverage (northern areas of the Iberian Peninsula, Fig. 2a) and high density of built up areas (main cities, i.e. Madrid and Barcelona, Fig. 2b), where additional increases in HONO levels up to $0.5 \mathrm{ppb}$ are observed. Figure 4 illustrates the HONO profile changes in urban areas of Madrid and Barcelona, and in areas of the Iberian Peninsula characterized by high LAI, such as Abanto.

15 The $\mathrm{HC} 47$ parameterization for the $\mathrm{NO}_{2}$ hydrolysis kinetics depends exclusively on the surface area to volume ratio (Eq. 1), resulting in an increase of HONO levels ranging from 200 to 800 ppt in the northern Iberian Peninsula and urban areas. The expression of $\mathrm{HCUCl}$ (Eq. 5), on the other hand, varies with the relative humidity in addition to $S / V$ ratio. Compared to the $\mathrm{HC} 47$ case, the impact of heterogeneous HONO production in $\mathrm{HCUCI}$ has a smaller geographical coverage, and the HONO increases from the BASE case range between 50 and 800 ppt. Higher relative humidity $(\mathrm{RH})$ occurring during nighttime (from 20:00 UTC, on) results in the differences in the predicted HONO levels up to 350 ppt between the $\mathrm{HC} 47$ and the $\mathrm{HCUCl}$ parameterization (Fig. 5). Therefore relative humidity is a key factor to be considered in the parameterization of the kinetics of the $\mathrm{NO}_{2}$ hydrolysis.

When the contribution of each process to the HONO peak (06:00 UTC) is quantified for a reduced domain over the Madrid area $\left(30 \times 30\right.$ cells, $\left.4 \times 4 \mathrm{~km}^{2}\right)$, results corroborate with the previous analysis (Table 4). Gas-phase chemistry leading to HONO formation is only responsible for at most $5.2 \%$ of the predicted peak HONO

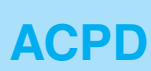

10, 28183-28230, 2010

\section{Different nitrous acid sources in the air quality levels}

M. Gonçalves et al.

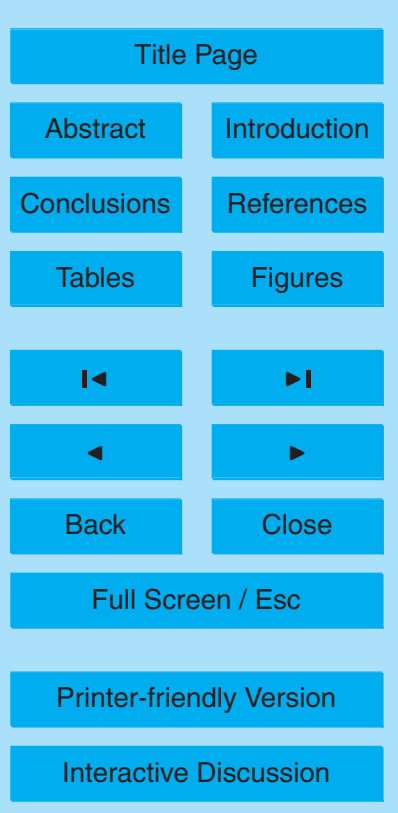


concentration in the area (EM08HCUCl case). Direct emissions constitute the main HONO source in all scenarios, with contributions to the HONO peak concentration ranging between $65.5 \%$ and $94.3 \%$ (EM08HC47 and $\mathrm{EM} 2 \mathrm{HCUCl}$, respectively). The relative importance of the $\mathrm{NO}_{2}$ hydrolysis on aerosol surfaces is negligible (around $50.1 \%$ ). Other processes could occur on aerosol surfaces that are not considered within this work, but further investigation on the kinetics and specific processes have to be performed in order to include them for modeling purposes. Results indicate that $\mathrm{NO}_{2}$ hydrolysis ocurring on ground surfaces (buildings and vegetation) contributes up to $30.3 \%$ of the peak HONO levels when the parameterization of Kurtenbach et 10 al. (2001) is applied (EM08HC47 case). The study case using the kinetics derived from Finlayson-Pitts et al. (2003) exhibits lower contribution from ground surfaces, $9.3 \%$ at the most (EM08HCUCl case), but as discussed above, the importance of Eq. (5) parameterization can be enhanced under high $\mathrm{RH}$ conditions. The average peak value ranges from $0.037 \mathrm{ppb}$ in the EM08HCUCl case to $0.106 \mathrm{ppb}$ in the EM2HC47 case

15 (Table 4) for a $120 \times 120 \mathrm{~km}^{2}$ domain centered in Madrid. This region also contains non-urban areas, so it cannot be compared with typical values measured in urban regions. In summary, direct emissions and $\mathrm{NO}_{2}$ hydrolysis are fundamental contributors to HONO levels. They should be included within air quality models, particularly in order to predict urban air quality levels, because in urban environments on-road traffic is a 20 main source of emissions and buildings provide an effective surface for heterogeneous reaction.

HONO concentrations in urban areas are in the order of several ppb (Table 3), and in rural environments, they usually range from 10 to 100 pptv (Wentzell et al., 2010). In order to assess the model ability to reproduce HONO profiles in rural environments, 25 a qualitative comparison against observations is performed. The Diel Oxidant Mechanism In relation to Nitrogen Oxides (DOMINO) campaign (Sörgel et al., 2010) provides HONO reference levels for the Iberian Peninsula (Fig. 6). The campaign was conducted from October to November, 2008, and measured HONO levels by means of a LOng Path Absorption Photometer (LOPAP) in the El Arenosillo station $\left(37^{\circ} 5^{\prime \prime} \mathrm{N}\right.$

\section{Different nitrous acid sources in the air quality levels}

M. Gonçalves et al.

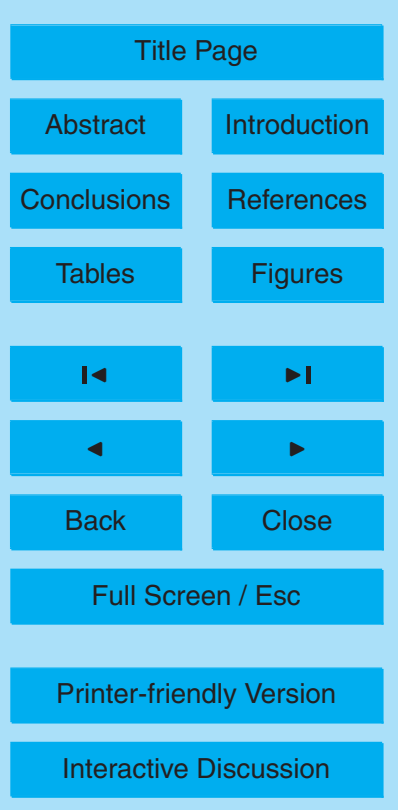


and $6^{\circ} 44^{\prime} \mathrm{W}$, Huelva, southwestern Spain). A quantitative model evaluation cannot be performed based on the DOMINO data, because model and observations do not correspond to the same period (18 June 2004 for the WRF-ARW/HERMES/CMAQ model simulations). The measurements are taken as a reference of the rural background 5 HONO levels in the Iberian Peninsula. The station is located in a forested area mainly composed of pine trees, and under specific meteorological situations, it can be slightly affected by an industrial plume originated $20 \mathrm{~km}$ away in the northwest direction, where a refinery and a power plant are located.

The improvement of the HONO profiles prediction is clear when introducing HONO emissions, especially in the EM2 case, producing an increase in the early morning and nighttime levels (up to 94 ppt at 23:00 UTC). EM2 case is studied as an upper limit, with a slight overestimation of HONO emissions, which suggests that there are additional sources contributing to the HONO levels apart from the emissions.

The availability of surfaces for the heterogeneous reaction in the El Arenosillo area 15 is sparse. Building surfaces are restricted to the Huelva area, a town accounting for 150000 inhabitants located $20 \mathrm{~km}$ away from the station, and the pine trees surrounding the station provide a relatively low surface area to volume ratio. Its LAI ranges from 1.0 to 1.5 , as derived from TERRA-MODIS satellite data, while the maximum LAI values for the Iberian Peninsula are of 6.5 in June (Fig. 2a). The largest impact on HONO concentration due to the heterogeneous chemistry is observed before dawn. Concentrations are up to $21.5 \mathrm{ppt}$ higher due to the $\mathrm{NO}_{2}$ hydrolysis on surfaces $(\mathrm{HC} 47)$ when the kinetics of Eq. (1) is included. The impact due to $\mathrm{HCUCl}$ parameterization is an order of magnitude lower (up to $2.9 \mathrm{ppt}$ ). In spite of the improvements, EM08HC47 and $\mathrm{EM} 08 \mathrm{HCUCl}$ cases slightly underestimate HONO levels before dawn. The vicinity of the industrial area could have interfered with some of the measurements and increased the background HONO levels. Though this effect, if it is indeed the cause for such discrepancy, should be masked by the long term campaign. During the simulated day (18 June 2004), the area was not affected by the industrial plume, and the estimated HONO for EM2 cases falls within the range of the observed values for nighttime (considering

\section{Different nitrous acid sources in the air quality levels}

M. Gonçalves et al.

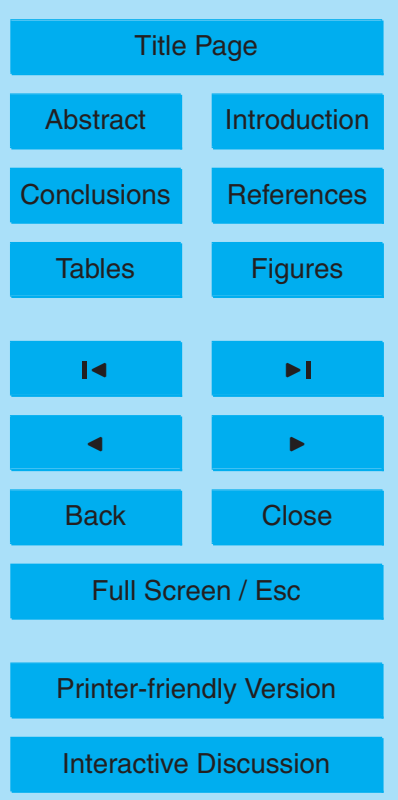


the minimum and maximum HONO levels). A slight overprediction is observed in the 14:00 to 16:00 UTC period, which could be attributed to the specific meteorological conditions of the selected day. The comparison with observations suggests that there may be additional surfaces available for the heterogeneous reaction in the El Arenosillo 5 area not currently considered in the model, or other unknown sources are contributing to HONO release during nighttime.

\subsection{Impact of HONO sources on gas-phase pollutants}

In the morning, HONO emissions photolyze to produce $\mathrm{OH}$ and $\mathrm{NO}$ that lead to rapid $\mathrm{NO}_{2}$ formation. $\mathrm{NO}_{2}$ levels increase up to $4.0 \mathrm{ppb}(8 \%)$ in the EM08 case and up to $9.0 \mathrm{ppb}(18 \%)$ in the EM2 case during the morning rush hour (from 06:00 to 10:00 UTC) in the urban areas. Heterogeneous chemistry, however, involves changes below $1.0 \mathrm{ppb}(1.8 \%)$ in the $\mathrm{NO}_{2}$ peak.

The hydroxyl radical release alters the oxidation capacity of the atmosphere, feeding into $\mathrm{HO}_{x}$ cycle in the troposphere and increasing $\mathrm{O}_{3}$ concentration, especially in downwind areas from the major $\mathrm{NO}_{\mathrm{x}}$ sources. In large urban areas such as Madrid and Barcelona, the impact of $\mathrm{OH}$ release via $\mathrm{HONO}$ photolysis is the greatest immediately after sunrise (in the time interval between 07:00 and 10:00 UTC), while the $\mathrm{O}_{3}$ concentrations are still low. In the EM08 case, the $\mathrm{O}_{3}$ hourly concentration increases up to $4.0 \mathrm{ppb}(7 \%)$ during the morning rush hour, and in the EM2 case, the increase is up to $10.0 \mathrm{ppb}(17 \%)$. The additional increase caused by heterogeneous chemistry on surfaces reaches up to $1.4 \mathrm{ppb}(2.3 \%)$ in the $\mathrm{HC} 47$ case and up to $0.8 \mathrm{ppb}(1.3 \%)$ in the $\mathrm{HCUCl}$ case. Overall, changes in $\mathrm{O}_{3}$ concentration are more pronounced in the $\mathrm{HC} 47$ than in the $\mathrm{HCUCl}$ case. Nevertheless, relative humidity plays an important role, and $\mathrm{O}_{3}$ production by $\mathrm{HCUCl}$ parameterization is higher for specific locations or time dicted by $\mathrm{HCUCl}$ than by $\mathrm{HC} 47$. Therefore, the introduction of the $\mathrm{RH}$ dependence in the heterogeneous chemistry kinetics affects not only HONO predictions, but also the secondary pollutants derived.

ACPD

$10,28183-28230,2010$

\section{Different nitrous acid sources in the air quality levels}

M. Gonçalves et al.

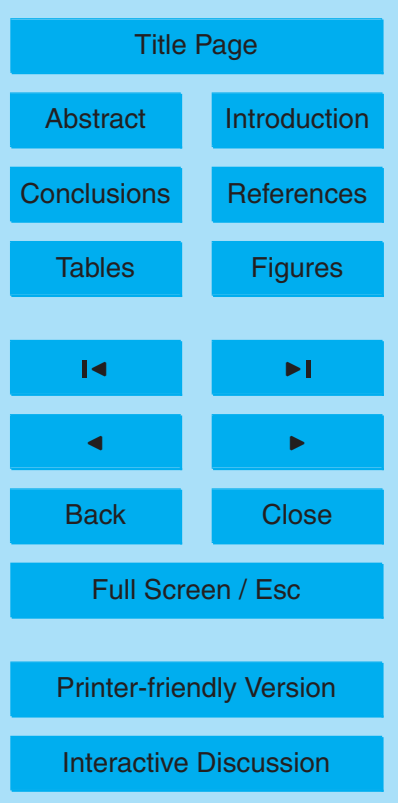

Interactive Discussion 
$\mathrm{O}_{3}$ peak concentrations occur in downwind areas from the main $\mathrm{NO}_{\mathrm{x}}$ sources later in the day (from 11:00 UTC to 15:00 UTC, depending on the location) and are affected by the HONO sources. HONO emissions (EM08) and heterogeneous production can raise the $\mathrm{O}_{3}$ peak concentration $0.7 \mathrm{ppb}(1.0 \%)$ in Madrid and from $3.3 \mathrm{ppb}, 4 \%$, ( $\left.\mathrm{HCUCl}\right)$ 5 to $4.0 \mathrm{ppb}, 4.5 \%$, (HC47) in Barcelona urban plumes (Fig. 8). The accuracy in predicting peak concentrations is of special concern for air quality modelers, due to the consequences of these high concentrations on human health. Therefore, changes in predictions from $1.0 \%$ to $4.5 \%$ are quite significant.

The increase of $\mathrm{O}_{3}$ levels in the early morning on urban areas is attributed to the $10 \mathrm{OH}$ release due to HONO photolysis. The specific contribution of HONO photolysis (Reaction R1) can be quantified through the Integrated Reaction Rate (IRR) analysis (Gipson, 1999), available in CMAQ model. IRR provides the contribution of each reaction in CB05 to the change in concentration of any species. When applied over the Madrid area $(30 \times 30$ cells, $4 \mathrm{~km} \times 4 \mathrm{~km})$, IRR shows a peak of HONO photolysis at $10.00 \mathrm{UTC}$, where $0.12 \mathrm{ppb} / \mathrm{h}$ of $\mathrm{OH}$ are released (BASE case). The EM08 case increases the $\mathrm{OH}$ production rate $11.7 \%$ at 10:00 UTC respect to the BASE case, while the EM2 case provides an increase of $32.7 \%$. Heterogeneous chemistry involves additional increases of $2.1 \%$ and $0.45 \%$ when the $\mathrm{HC} 47$ and $\mathrm{HCUCl}$ kinetics are used, respectively (Fig. 7). These findings corroborate the fact that the main effects on secondary gas-phase pollutants in urban areas occur right after sunrise. Also, the impact of the HONO emissions is shown to be larger than the impact of the parameterized ground surface heterogeneous chemistry in urban settings, where the pollutants formation is clearly dominated by on-road traffic emissions.

\subsection{Impacts of additional HONO sources on the secondary $\mathrm{PM}_{2.5}$}

25 The addition of direct and heterogeneous HONO sources also has a significant impact on the aerosol concentrations over the Iberian Peninsula. The $\mathrm{OH}$ release with sunlight promotes the oxidation of pollutants. These oxidized pollutants can act as aerosol precursors, leading to $\mathrm{PM}_{2.5}$ increases. The most affected regions are those in close 28202

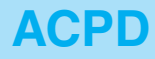

10, 28183-28230, 2010

\section{Different nitrous acid sources in the air quality levels}

M. Gonçalves et al.

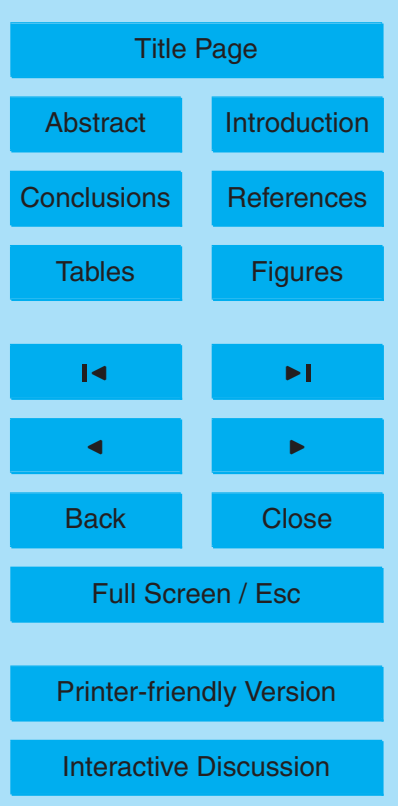


proximities to main emission sources: the major urban areas of the Iberian Peninsula and power plants and industrial sites, specifically the northwestern Iberian Peninsula and the Algeciras region (Fig. 9a). The introduction of on-road traffic emissions of HONO (EM08) increases up to $2.7 \mu^{-3} \mathrm{~g} \mathrm{~m}^{-3}$ (4.5\%) $\mathrm{PM}_{2.5}$ levels in the main urban ar5 eas. If $\mathrm{HONO}$ emissions are included as $2 \%$ of the total emitted $\mathrm{NO}_{\mathrm{x}}(\mathrm{EM} 2)$, northern industrial areas are the most affected, showing increases in $\mathrm{PM}_{2.5}$ by up to $3.0 \mu \mathrm{g} \mathrm{m}^{-3}$ $(11 \%)$. Further increases in $\mathrm{PM}_{2.5}$ levels of up to $1.4 \mu \mathrm{g} \mathrm{m}^{-3}(5.45 \%)$ are attributed to the $\mathrm{NO}_{2}$ hydrolysis on vegetation surfaces in the northern region in the $\mathrm{HCUCl}$ case. $\mathrm{HC} 47$ involves changes up to $1.2 \mu \mathrm{g} \mathrm{m}^{-3}(4.7 \%)$ for the same area. The peak values 10 across the domain are found in locations with the highest surface to volume ratio available for the HONO production, constituted by the urban areas and densely forested regions of the Iberian Peninsula, as well as near the main emission sources, industrial and urban areas.

The increase in $\mathrm{PM}_{2.5}$ levels in urban areas is mostly attributed to changes in nitrates $15 \quad\left(\mathrm{NO}_{3}\right)$ and secondary organic aerosols (SOA). The production of $\mathrm{OH}$ from HONO photolysis in urban areas in the early morning increases the oxidation capacity of the atmosphere, thus the high $\mathrm{NO}_{\mathrm{x}}$ levels from traffic emissions are likely to further oxidize and yield nitric acid $\left(\mathrm{HNO}_{3}\right)$. Gas phase $\mathrm{HNO}_{3}$ can then partition into aerosol phase, or be absorbed onto existing aerosols to form nitrate aerosols. As expected, the HONO effect is the greatest between 06:00 and 11:00 UTC, especially in those areas with high relative humidity (e.g. the Barcelona urban area), where differences in nitrate levels up to $0.7 \mu \mathrm{g} \mathrm{m}^{-3}(14 \%)$ and $0.65 \mathrm{\mu g} \mathrm{m}^{-3}(13 \%)$ in the EM08HC47 and EM08HCUCl cases are found (Fig. 9b).

Similarly, the increase in oxidative capacity by morning $\mathrm{OH}$ production also leads to an increase in secondary organic aerosol yield from the heavy urban traffic volatile organic compound (VOC) emissions. As the result, the SOA concentration increases in

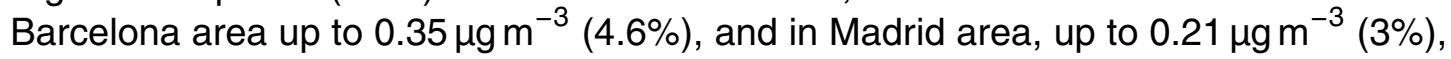
for EM08HC47 and EM08HCUCl cases (Fig. 9c).
ACPD

10, 28183-28230, 2010

\section{Different nitrous acid sources in the air quality levels}

M. Gonçalves et al.

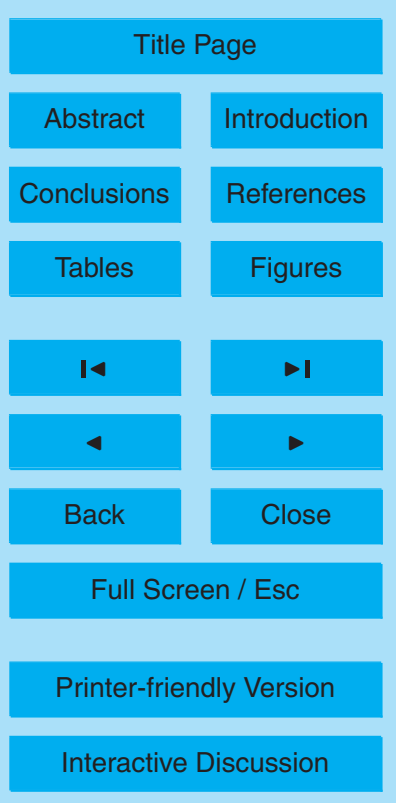


Scattered over the Atlantic Ocean and the Mediterranean Sea, increases in chlorine aerosols are observed, which is likely to be derived from the increase of $\mathrm{OH}$ availability as a result of the HONO emissions from ships traffic (Fig. 9d); they are not, however, quantitatively significant compared with overall aerosol levels.

5 In downwind areas from the major power plants, the increase $\mathrm{PM}_{2.5}$ concentrations by the introduction of HONO sources is mainly produced by a change in the sulfate $\left(\mathrm{SO}_{4}\right)$ and ammonium $\left(\mathrm{NH}_{4}\right)$ levels. In Spain, there are still a number of conventional power plants that use coal as a fuel, which are important sources of sulfur oxides. In 2004 , the contribution of these installations to total $\mathrm{SO}_{\mathrm{x}}$ accounted for $79 \%$ of the $1.3 \mathrm{kT}$ 10 emitted, according to the National Emissions Inventory (MARM, 2010). The sulfur oxides are precursors of sulfate aerosols, formation of which depends on the relative humidity and the oxidation capacity of the atmosphere. The release of $\mathrm{OH}$ in the early morning due to $\mathrm{HONO}$ photolysis increases $\mathrm{SO}_{4}$ formation by up to $0.35 \mathrm{\mu g} \mathrm{m}^{-3}(2.9 \%)$ for the EM08HC47 case in the northern region of the Iberian Peninsula (Fig. 9e). This 15 region is characterized by a high vegetation density (see Fig. $2 \mathrm{a}$ ), high values of relative humidity, and concentrated agricultural activities development that act as sources of primary ammonia. The combination of these factors together with the emissions of sulfur oxides from the power plants can lead to the formation of ammonium sulfate $\left(\left(\mathrm{NH}_{4}\right)_{2} \mathrm{SO}_{4}\right)$, raising both the levels of ammonia and sulfate in the aerosol phase 20 (Fig. 9e and f).

The introduction of heterogeneous HONO chemistry results in not only changes in PM level, but also PM composition. Such phenomenon could be attributed the differences in the treatment of $\mathrm{NO}_{2}$ uptake on ground and aerosol surfaces. The $\mathrm{NO}_{2}$ hydrolysis on ground surfaces produces $\mathrm{HNO}_{3}$ that is considered sticky and remains in the surfaces, not affecting further the tropospheric chemistry. In order to warrant mass conservation, this characteristic is treated through the deposition module in CMAQv4.7, being that the $\mathrm{HNO}_{3}$ productions on surfaces treated as nitrogen sinks in the first layer of the model. The same approach is not applicable, however, to the $\mathrm{NO}_{2}$ hydrolysis on aerosol surfaces, because aerosols are distributed throughout different layers in height

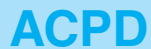

10, 28183-28230, 2010

\section{Different nitrous acid sources in the air quality levels}

M. Gonçalves et al.

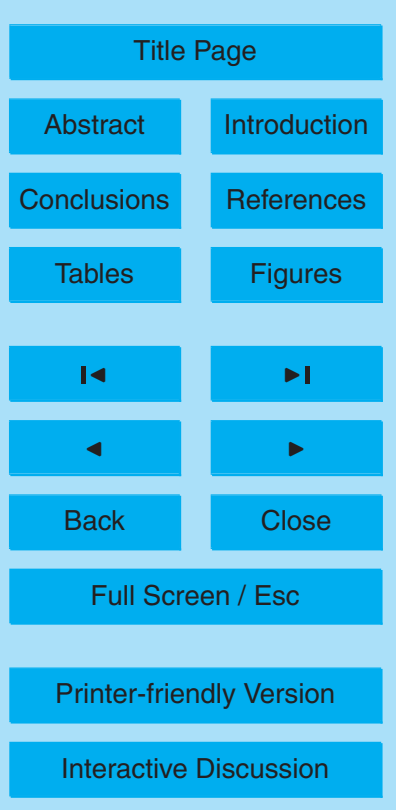


and not at the surface layer where deposition occurs only. Therefore, after $\mathrm{NO}_{2}$ hydrolysis on aerosol surfaces, $\mathrm{HNO}_{3}$ is released back into the atmosphere, leading to an increase in nitrate production. The nitrate mass increase is not quantitatively significant, but it affects the ammonia-sulfate regime. The BASENA case shows a $\mathrm{SO}_{4}$ 5 to $\mathrm{NH}_{4}$ molar ratio close to 0.5 , (Fig. 10) corresponding to the ammonium sulfate formation. The BASE case, which considers $\mathrm{NO}_{2}$ hydrolysis on aerosol surfaces, shows slightly higher ratios. Ratios higher than 0.5 indicate an ammonia deficient regime and an acidic aerosol system, where the nitrate concentration is strongly dependent on ambient relative humidity (Binkowski and Roselle, 2003). When the HONO production 10 on aerosol surfaces is activated and $\mathrm{HNO}_{3}$ is released (BASE), the ammonia available to react with sulfate decreases. Figure 10 (lower panels) for various urban locations suggests either the formation of ammonium bisulfate or the production of ammonium nitrate. The effect is lower in the northern region (Fig. 10, upper panels) due to the abundance of ammonia sources. A detailed analysis of the relative humidity conditions should be performed to further analyze the aerosols phase equilibrium.

\section{Conclusions}

HONO is of significant importance to the chemistry of the troposphere since it can produce $\mathrm{OH}$ via photolysis, especially in urban areas. $\mathrm{OH}$ is a powerful oxidant that alters both gas-phase pollutants and aerosols concentration in the atmosphere. High air pollution levels of anthropogenic origin are usually present in urban environments, especially concerning $\mathrm{NO}_{x}$ and particulate matter. Under such conditions, $\mathrm{OH}$ sources and interactions need to be defined accurately in order to properly model the dynamics of secondary pollutants in the atmosphere.

Gas-phase chemistry involving HONO is well known and it is included in most of 25 the latest state-of-the-art air quality models. Gas phase chemistry alone, however, is unable to reproduce observed HONO dynamics, which in urban areas are characterized by a build-up during nighttime and a dramatic decrease after dawn due to

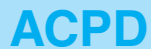

$10,28183-28230,2010$

\section{Different nitrous acid sources in the air quality levels}

M. Gonçalves et al.

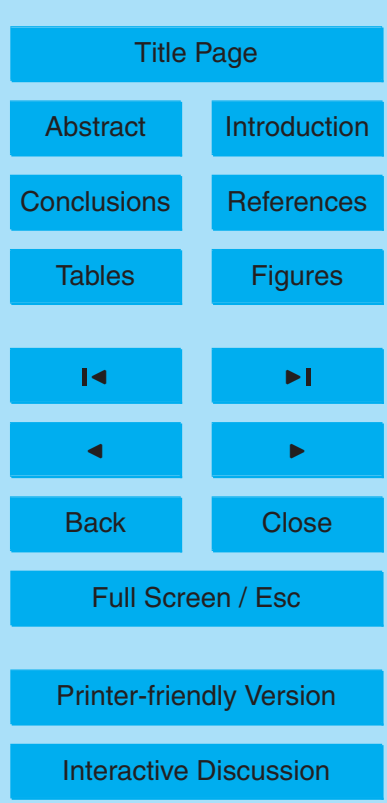


photolysis. The highest peak concentrations before sunrise reported up to date was $15 \mathrm{ppb}$, observed at Los Angeles in 1994, although levels reported in other locations are usually lower, ranging from 0.4 to $7 \mathrm{ppb}$. Hence, air quality models require additional sources of $\mathrm{HONO}$, and previous studies have shown that direct emissions and $5 \mathrm{NO}_{2}$ hydrolysis on wet surfaces may be important. In this study, the introduction of HONO emissions and heterogeneous chemistry processes is shown to improve significantly HONO predictions in urban areas of the Iberian Peninsula by means of the WRF-ARW/HERMES/CMAQ model.

Two different parameterizations for emissions are included. First, a "low HONO to $10 \mathrm{NO}_{\mathrm{x}}$ ratio" case (EM08), including $\mathrm{HONO}$ as $0.8 \%$ of $\mathrm{NO}_{\mathrm{x}}$ from mobile sources, and second, a "high $\mathrm{HONO}$ to $\mathrm{NO}_{\mathrm{x}}$ ratio" case (EM2), including $\mathrm{HONO}$ as $2 \%$ of $\mathrm{NO}_{\mathrm{x}}$ from all sources. The $\mathrm{NO}_{2}$ hydrolysis on surfaces is included as the most probable heterogeneous chemistry process leading to HONO formation. Laboratory studies show that the kinetics of this reaction is pseudo-first order in $\mathrm{NO}_{2}$ and shows a strong de$\mathrm{NO}_{2}$ hydrolysis kinetics. First, the current expression included in the CMAQv4.7 model (Sarwar et al., 2008) which depends on the available surface for reaction (HC47). Second, $\mathrm{HCUCl}$, a new expression derived which, apart from the available surface for the reaction, includes the relative humidity dependence derived from different laboratory 20 studies (Finlayson-Pitts et al., 2003).

On-road transport stands out as a main source of HONO in urban areas. Results show that direct emissions contribute from $65 \%$ to $95 \%$ to HONO peak concentration in urban environments. The $\mathrm{NO}_{2}$ hydrolysis on ground surfaces also constitutes an important HONO source in urban areas, with contributions to HONO peak up to $65 \%$.

25 The available surface for reaction is a key factor for HONO production via heterogeneous reaction, so it is especially important in northern areas of the Iberian Peninsula, characterized by dense vegetation and high leaf area indexes, and in urban areas, due to buildings surface. For the same reason, the effects of $\mathrm{NO}_{2}$ hydrolysis on aerosol surfaces are negligible. Other processes occurring on aerosols could be of significance,
ACPD

10, 28183-28230, 2010

\section{Different nitrous acid sources in the air quality levels}

M. Gonçalves et al.

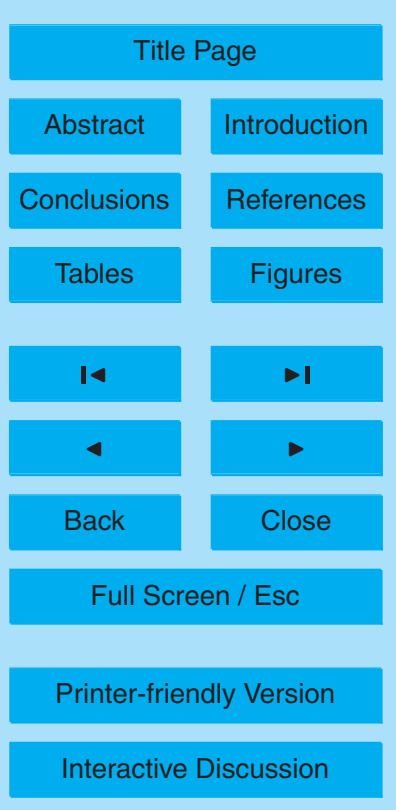


but they are not addressed within this work because of the lack of specific data related to their mechanisms and kinetics. Although the crude $\mathrm{HC} 47$ parameterization provides higher overall $\mathrm{HONO}$ concentration than the $\mathrm{HCUCl}$, the consideration of the relative humidity in the $\mathrm{HCUCl}$ parameterization involves greater variability of the estimated 5 reaction rate that accounts for different geographical regions. During nighttime at locations with typical high relative humidity values, such as the northern region of the Iberian Peninsula and the Barcelona urban area, $\mathrm{HCUCl}$ method is more effective in HONO production than $\mathrm{HC} 47$ parameterization.

The addition of HONO emissions and heterogeneous chemistry also improves model 10 in southern Spain of $0.1 \mathrm{ppb}$ on average are reproduced by the model when the "high
$\mathrm{HONO}$ to $\mathrm{NO}_{\mathrm{x}}$ emissions ratio" is applied. Taking into account that this case is considered as an upper limit for HONO emissions, the results suggest that in order to capture HONO nighttime and early morning peaks while using more realistic HONO emissions 15 factor, additional HONO sources or a better representation of available surfaces for reaction are necessary.

Urban HONO levels of up to $2.0 \mathrm{ppb}$ are predicted when emissions and $\mathrm{NO}_{2}$ hydrolysis are included in the model (EM2HC47). The contribution to the increase in $\mathrm{OH}$ release due to these HONO sources is significant. When quantified in the Madrid area, $\mathrm{OH}$ production via HONO photolysis can increase from $11.7 \%$ to $32.7 \%$, especially in the early morning (from 06:00 to 10:00 UTC), and major changes in $\mathrm{O}_{3}$ levels are found from 07:00 to 10:00 UTC. $\mathrm{O}_{3}$ increases in urban areas due to the addition of HONO emissions range from $7 \%$ (EM08) to 17\% (EM2). Heterogeneous chemistry provides additional $\mathrm{O}_{3}$ increases from 1.3\% ( $\mathrm{HCUCl}$ ) to 2.3\% ( $\left.\mathrm{HC} 47\right)$. Overall, changes in $\mathrm{O}_{3}$ concentration are more pronounced in the $\mathrm{HC} 47$ than in the $\mathrm{HCUCl}$ case. Nevertheless, relative humidity plays an important role, and $\mathrm{O}_{3}$ production by $\mathrm{HCUCl}$ parameterization can be enhanced at high relative humidity levels. Moreover, the addition of $\mathrm{HONO}$ sources affects the $\mathrm{O}_{3}$ peak prediction in downwind areas from main cities, increasing predicted concentrations by up to $4.5 \%$.

\section{ACPD}

10, 28183-28230, 2010

\section{Different nitrous acid sources in the air quality levels}

M. Gonçalves et al.

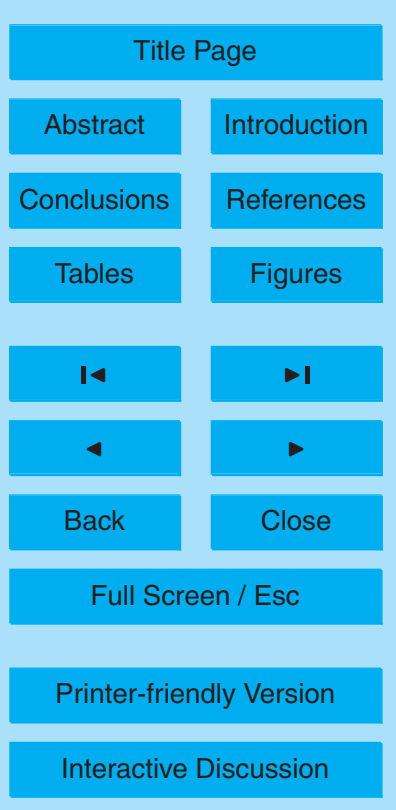


Particulate matter levels are also altered by the introduction of HONO sources. Changes in concentration of up to $2.6 \mu \mathrm{g} \mathrm{m}^{-3}$ for $\mathrm{PM}_{2.5}(16 \%$, in the EM08HC47 case) are observed in downwind areas from the largest point sources of emissions and major cities. The change in the fine aerosol fraction is mainly attributed to nitrates and 5 SOA formation in urban areas, and to sulfates and ammonia in regions downwind from power plants. The increase in nitrate levels is attributed to the increase production of nitric acid, derived mainly from the reaction of $\mathrm{OH}$ and $\mathrm{NO}_{2}$. Also, the production of $\mathrm{OH}$ in urban areas during the early morning has the capability of oxidizing the freshly emitted VOCs from traffic emissions, leading to the formation of SOA. OH release due 10 to HONO emissions from ships traffic slightly affects chlorine levels over the Mediterranean Sea, although variations are not quantitatively significant. In the northern region of the Iberian Peninsula, the $\mathrm{SO}_{\mathrm{x}}$ emissions from power plants are further oxidized by reaction with $\mathrm{OH}$ to form sulfuric acid, leading to subsequent sulfates production. If the gas-phase chemistry alone is considered, the sulfate to ammonia molar ratio is typical 15 for ammonium sulfate presence, being around 0.5. When additional HONO sources are included, the ratio increases to 1.0-1.5, indicating an acidic aerosol regime where ammonia is deficient. This fact can potentially be attributed to the formation of nitrates that deplete ammonia or to the formation of ammonium bisulfate. Therefore, HONO addition involves significant changes both in $\mathrm{PM}_{2.5}$ levels and composition.

20 In summary, the addition of HONO sources on air quality models is crucial for proper prediction of ambient HONO mixing ratio, and it has a significant impact in the model ability to predict $\mathrm{O}_{3}$ and $\mathrm{PM}_{2.5}$ levels. The $\mathrm{NO}_{2}$ hydrolysis on ground surfaces is an important source of HONO in the atmosphere; emissions also contribute significantly to HONO levels prediction, especially in urban areas. Nevertheless, additional HONO sources have to be explored and tested within air quality models in order to improve air pollutant predictions.

Acknowledgements. The authors gratefully acknowledge the collaboration of the AirUCl laboratory of the University of California Irvine and especially Barbara Finlayson-Pitts for the helpful discussions. The air quality observations for $\mathrm{O}_{3}, \mathrm{NO}_{2}$ and particulate matter were provided

\section{Different nitrous acid sources in the air quality levels}

M. Gonçalves et al.

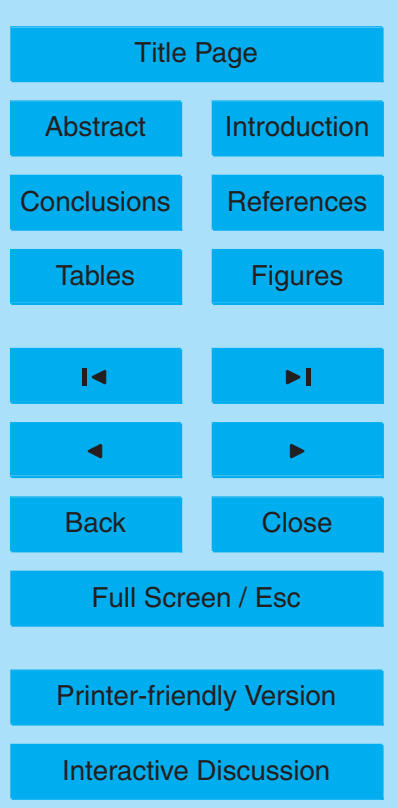


by the Spanish Air Quality Networks, EMEP and CSIC networks. The processed TERRAMODIS satellite data were obtained from the Climate and Vegetation Research Group of the Boston University. Special thanks to M. T. Pay for the help in the observation data treatment, L. González for the computation of emissions, and M. Sörgel for providing the HONO obser5 vation data within the DOMINO campaign. This project is funded by the CALIOPE project of the Spanish Ministry of the Environment (441/2006/3-12.1, A357/2007/2-12.1,157/PC08/312.0). All the simulations were performed in the Marenostrum Supercomputer of the Barcelona Supercomputing Center-Centro Nacional de Supercomputación (Barcelona, Spain).

\section{References}

Acker, K., Febo, A., Trick, S., Perrino, C., Bruno, P., Wiesen, P., Möller, D., Wieprecht, W., Auel, R., Giusto, M., Geyer, A., Platt, U., and Allegrini, I.: Nitrous acid in the urban area of Rome, Atmos. Environ., 40, 3123-3133, 2006.

Alicke, B., Platt, U., and Stutz, J.: Impact of nitrous acid photolysis on the total hydroxyl radical budget during the Limitation of Oxidant Production/Pianura Padana Produzione di Ozono study in Milan, J. Geophys. Res., 107(D22), 8196, doi:10.1029/2000JD000075, 2002.

Alicke, B., Geyer, A., Hofzumahaus, A., Holland, F., Konrad, S., Patz, H. W., Schafer, J., Stutz, J., Volz-Thomas, A., and Platt, U.: OH formation by HONO photolysis during the BERLIOZ experiment, J. Geophys. Res., 108(D4), 8247, doi:10.1029/2001JD000579, 2003.

Ammann, M., Kalberer, M., Jost, D. T., Tobler, L., Rossler, E., Piguet, D., Gaggeler, H. W., and Baltensperger, U.: Heterogeneous production of nitrous acid on soot in polluted air masses, Nature, 395(6698), 157-160, 1998.

Atkinson, R., Baulsch, D. L., Cox, R. A., Hampton, R. F., Kerr, J. A., Rossi, M. J., and Troe, J.: Evaluated kinetics, photochemical and heterogeneous data, J. Phys. Chem., 26(3), 5211012, 1997.

Baldasano, J. M., Güereca, L. P., López, E., Gassó, S., and Jiménez-Guerrero, P.: Development of a high-resolution $(1 \mathrm{~km} \times 1 \mathrm{~km}, 1 \mathrm{~h})$ emission model for Spain: the High-Elective Resolution Modelling Emission System (HERMES), Atmos. Environ., 42, 7215-7233, 2008a.

Baldasano, J. M., Jiménez-Guerrero, P., Jorba, O., Pérez, C., López, E., Güereca, P., Martín, F., Vivanco, M. G., Palomino, I., Querol, X., Pandolfi, M., Sanz, M. J., and Diéguez, J. J.:
ACPD

10, 28183-28230, 2010

\section{Different nitrous acid sources in the air quality levels}

M. Gonçalves et al.

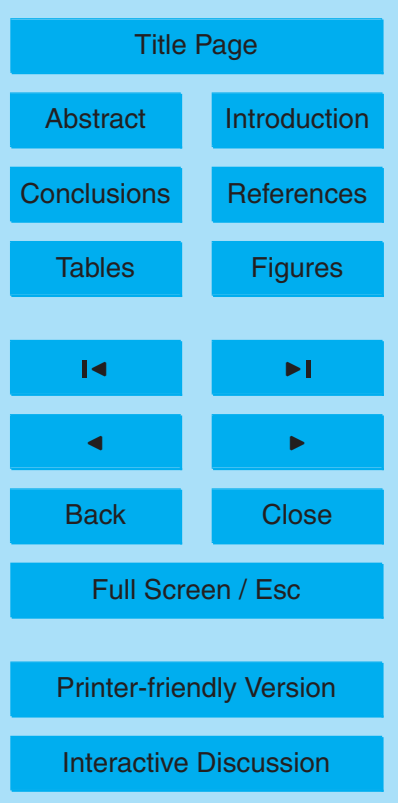


islands and Canary islands e first annual evaluation and ongoing developments, Adv. Sci. Res., 2, 89-98, 2008b.

Baldasano, J. M., Pay, M. T., Jorba, O., Piot, M., Jiménez-Guerrero, P., and Gassó, S.: An annual assessment of air quality with the CALIOPE modeling system over Spain, Sci. Total 5 Environ., submitted, 2010.

Bejan, Y., Abd el Aal, I., Barnes, I., Benter, T., Bohn, B., Wiesen, P., and Kleffmann, J.: The photolysis of ortho-nitrophenols: a new gas-phase source of HONO, Phys. Chem. Chem. Phys., 8, 2028-2035, doi:10.1039/b516590c, 2006.

Binkowski, F. S. and Roselle, S. J.: Models-3 Community Multiscale Air Quality (CMAQ) model aerosol component. 1. Model description, J. Geophys. Res., 108(D6), 4183, doi:10.1029/2001JD001409, 2003.

Byun, D. W. and Ching, J. K. S.: Science Algorithms of the EPA Models-3 Community Multiscale Air Quality (CMAQ) Modeling System, Atmospheric Modeling Division, National Exposure Research Laboratory, US-EPA, 1999.

Byun, D. and Schere, K. L.: Review of the governing equations, computational algorithms, and other components of the Models-3 Community Multiscale Aair Quality (CMAQ) modeling system, Appl. Mech. Rev., 59(2), 51-77, 2006.

Carter, W. P. L.: Implementation of the SAPRC-99 chemical mechanism into the Models-3 framework, Report for the US-EPA January 29, 2000.

20 Carter, W. P. L.: Development of the SAPRC-07 chemical mechanism and updated ozone reactivity scales, Report to the California Air Resources Board (Contracts No. 03-318, 06408, and 07-730), 27 January, 2010.

CLC: CORINE (Coordination of Information of the Environment) Land Cover 2000, Ministerio de Fomento, España, available at: http://www.fomento.es/MFOM/LANG_CASTELLANO/ DIRECCIONES_GENERALES/INSTITUTO_GEOGRAFICO/Teledeteccion/corine/clc2000/ Image+2000, 2000.

DeMoore, W. B., Sander, S. P., Golden, D. M., Hampson, R. F., Kurlyo, M. J., Howard, C. J., Ravishankara, A. R., Kolb, C. E., and Molina, M. J.: Chemical Kinetics and Photochemical Data for Use in Stratospheric Modeling, Evaluation number 12, JPL publication 97-4, Jet $30 \quad$ Propulsion Laboratory, California Institute of Technology, Pasadena, California, 1997.

Derognat, C., Beekmann, M., Baeumle, M., Martin, D., and Schmidt, H.: Effect of biogenic volatile organic compound emissions on tropospheric chemistry during the Atmospheric PolIution Over the Paris Area(ESQUIF) campaign in the lle-de-France region, J. Geophys. Res.,

\section{Different nitrous acid sources in the air quality levels}

M. Gonçalves et al.

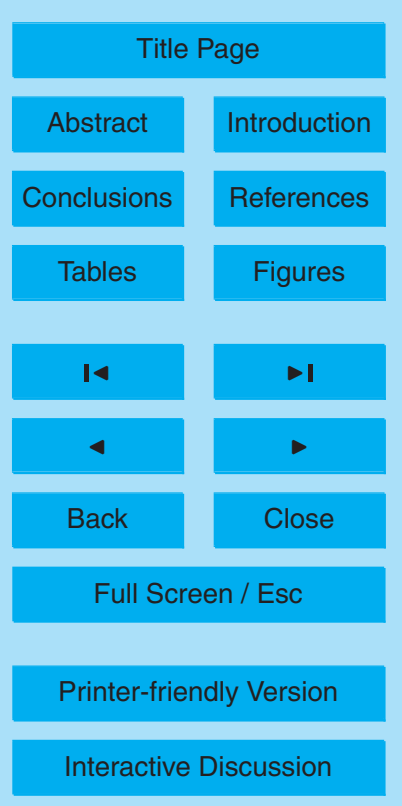


108(D17), 8560, doi:10.1029/2001JD001421, 2003.

DGT: Dirección General de Tráfico. Estadísticas e Indicadores, available at: http://www.dgt.es/ portal/es/seguridad_vial/estadistica/parque_vehiculos/series_historicas_parque/, 2010.

Edney, E. O., Kleindienst, T. E., Lewandowski, M., and Offenberg, J. H.: Updated SOA chemical mechanism for the Community Multi-Scale Air Quality model, EPA 600/X-07/025, US Environmental Protection Agency, Research Triangle Park, North Carolina, 2007.

EEA: Spatial assessment of $\mathrm{PM}_{10}$ and ozone concentrations in Europe, 2005, EEA Technical Report, no. 1/2009. ISSN 1725-2237, Luxembourg: Office for Official Publications of the European Communities, 2009.

10 EEA/EMEP-CORINAIR: EEA Emissions Inventory Guidebook, Technical Report no. 6/2009, Published by the EEA, 19 June, available at: http://www.eea.europa.eu/publications/ emep-eea-emission-inventory-guidebook-2009, 2009.

Elshorbany, Y. F., Kurtenbach, R., Wiesen, P., Lissi, E., Rubio, M., Villena, G., Gramsch, E., Rickard, A. R., Pilling, M. J., and Kleffmann, J.: Oxidation capacity of the city air of Santiago, Chile, Atmos. Chem. Phys., 9, 2257-2273, doi:10.5194/acp-9-2257-2009, 2009.

Finlayson-Pitts, B. J., Wingen, L. M., Sumner, A. L., Syomin, D., and Ramazan, K. A.: The heterogeneous hydrolysis of NO2 in laboratory systems and in outdoor and indoor atmospheres: An integrated mechanism, Phys. Chem. Chem. Phys., 5, 223-242, 2003.

Foley, K. M., Roselle, S. J., Appel, K. W., Bhave, P. V., Pleim, J. E., Otte, T. L., Mathur, R., Sarwar, G., Young, J. O., Gilliam, R. C., Nolte, C. G., Kelly, J. T., Gillialand, A. B., and Bash, J. O.: Incremental testing of the Community Multiscale Air Quality (CMAQ) modeling system version 4.7, Geosci. Model Dev., 3, 205-226, 2010.

Ganguly, S., Schull, M. A., Samanta, A., Shabanov, N. V., Milesi, C., Nemani, R. R., Knyazikhin, Y., and Myneni, R. B.: Generating vegetation leaf area index earth system data record from multiple sensors. Part 1: Theory, Remote Sens. Environ., 112, 4333-4343, 2008.

Gery, M. W., Whitten, G. Z., and Killus, J. P.: Development and testing of the CBM-IV for urban and regional modeling, Report for the US-EPA no. EPA/600/S3-88/012 April 1988.

Gipson, L. G.: Science Algorithms of the EPA Models-3 Community Multiscale Air Quality (CMAQ) Modeling System: Process Analysis, EPA/600/R-99/030, US Environmental Proso tection Agency, Research Triangle Park, North Carolina, available at: http://www.epa.gov/ asmdnerl/CMAQ/CMAQscienceDoc.html, 1999.

Gong, S. L.: A parameterization of sea-salt aerosol source function for sub- and super-micron particles, J. Geophys. Res., 17, 1097, doi:10.1029/2003GB002079, 2003.

\section{Different nitrous acid sources in the air quality levels}

M. Gonçalves et al.

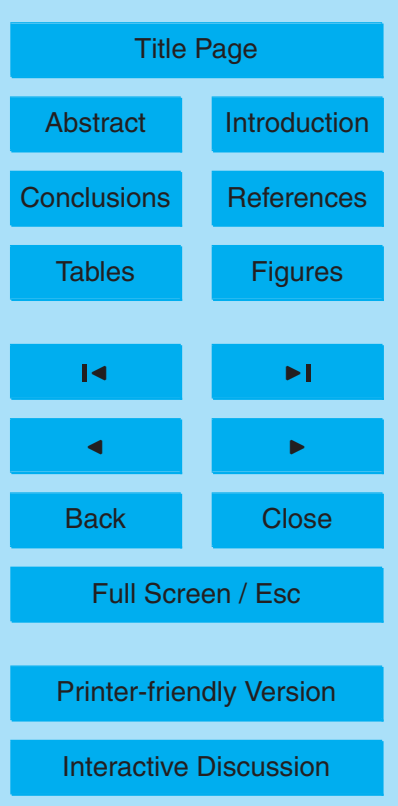


Griffin, R. J., Dabdub, D., and Seinfeld, J. H.: Secondary organic aerosol, 1, Atmospheric chemical mechanism for production of molecular constituents, J. Geophys. Res., 107(D17), 4332, doi:10.1029/2001JD000541, 2002.

Gutzwiller, L., Arens, F., Baltensperger, U., Gaggeler, H. W., and Ammann, M.: Significance of semivolatile diesel exhaust organics for secondary HONO formation, Environ. Sci. Tech., 36, 677-682, 2002.

Harley, R. A.: Impact of improved emissions characterization for nitrogen-containing air pollutants in the South Coast Air Basin, California Environmental Protection Agency, Air Resources Board, Research Division, Contract no. 93-310, Final report, available at: http: //www.arb.ca.gov/research/apr/past/93-310.pdf, May 1996.

INERIS: Documentation of the Chemical Transport Model CHIMERE (vs. 2008), Copyright (C) 2007 Institut Pierre-Simon Laplace, INERIS, LISA (CNRS), available at: http://www.Imd. polytechnique.fr/chimere/download.php, 2009.

IUPAC: Evaluated Kinetic and Photochemical Data, IUPAC Subcommittee on Gas Kinetic Data

15 Evaluation for Atmospheric Chemistry, Web Version, available at: http://www.iupackinetic.ch. cam.ac.uk, 2006.

Jeffries, H. E., Voicu, I., and Sexton, K.: Experimental Tests of Reactivity and Reevaluation of The Carbon Bond Four Photochemical Reaction Mechanism, Final report for Cooperative Agreement No. R828906, US-EPA, 2002.

20 Jenkin, M. E., Utembe, S. R., and Derwent, R. G.: Modelling the impact of elevated primary $\mathrm{NO} 2$ and HONO emissions on regional scale oxidant formation in the UK, Atmos. Environ., 42, 323-336, 2008.

Jiménez, P., Lelieveld, J., and Baldasano, J. M.: Multiscale modelling of air pollutants dynamics 15 in the northwestern Mediterranean basin during a typical summertime episode, J. Geophys. Res., 111, D18306, doi:10.1029/2005JD006516, 2006.

Jiménez-Guerrero, P., Jorba, O., Pérez, C., and Baldasano, J. M.: Annual High-Resolution Simulations and Evaluation of Particulate Matter in the Iberian Peninsula in a Supercomputing Framework, ACCENT/GLOREAM Workshop, Paris (France), 11-13 October, 2006.

Jiménez-Guerrero, P., Pay, M. T., Jorba, O., Piott, M., and Baldasano, J. M.: Evaluating the annual performance of an air quality forecasting system (CALIOPE) with high resolution for Europe and Spain, ACCENT/GLOREAM Workshop, Antwerp (Belgium), 29-31 October, 2008.

Kaiser, E. W. and Wu, C. H.: A Kinetic study of the Gas Phase Formation and Decomposition

\section{Different nitrous acid sources in the air quality levels}

M. Gonçalves et al.

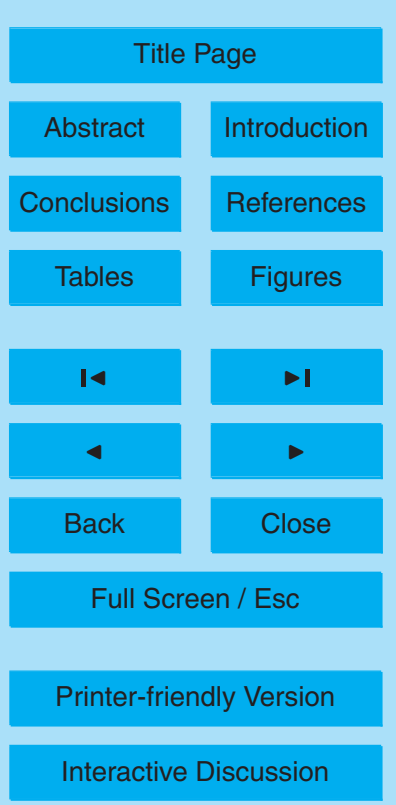


Reactions of Nitrous Acid, J. Phys. Chem., 81, 1701-1706, 1977.

Kirschtetter, T. W., Harley, R. A., and Littlejohn, D.: Measurement of Nitrous Acid in Motor Vehicle Exhaust, Environ. Sci. Technol., 30, 2843-2849, 1996.

Kleffmann, J., Becker, K. H., and Wiesen, P.: Heterogeneous $\mathrm{NO}_{2}$ conversion processes on $5 \quad$ acid surfaces: possible atmospheric implications, Atmos. Environ., 32, 2721-2729, 1998.

Kleffmann, J., Kurtenbach, R., Lörzer, J., Wiesen, P., Kalthoff, N., Vogel, B., and Vogel, H.: Measured and simulated vertical profiles of nitrous acid - Part I: Field measurements, Atmos. Environ., 37, 2949-2955, 2003.

Kurtenbach, R., Becker, K. H., Gomes, J. A. G., Kleffmann, J., Lorzer, J. C., Spittler, M., Wiesen, P., Ackermann, R., Geyer, A., and Platt, U.: Investigations of emissions and heterogeneous formation of HONO in a road traffic tunnel, Atmos. Environ., 35, 3385-3394, 2001.

Lammel, G. and Cape, J. N.: Nitrous acid and nitrite in the atmosphere, Chem. Soc. Rev., 25, 361-369, 1996.

Lattuati, M.: Contribution à l'étude du bilan de l'ozone troposphérique à l'interface de l'Europe et de l'Atlantique Nord: modélisation lagrangienne et mesures en altitude, Thèse de sciences, Université Paris 6, France, 1997.

Li, G., Lei, W., Zavala, M., Volkamer, R., Dusanter, S., Stevens, P., and Molina, L. T.: Impacts of HONO sources on the photochemistry in Mexico City during the MCMA-2006/MILAGO Campaign, Atmos. Chem. Phys., 10, 6551-6567, doi:10.5194/acp-10-6551-2010, 2010.

MARM: Inventario de emisiones a la atmósfera de España, Edición 2010, Serie 1990-2008. Sumario de resultados de acidificadores, eutrofizadores y precursors del ozono, Ministerio de Medio Ambiente Rural y Marino. Secretaría de Estado de Cambio Climático, Dirección General de Calidad y Evaluación Ambiental, Unidad de información ambiental estratégica, Madrid, available at: $\quad$ http://www.mma.es/secciones/calidad_contaminacion/atmosfera/emisiones/pdf/ Sumario_de_Inventario_Nacional_de_Emisiones_OTROS_GASES_serie_1990-2008.pdf, April 2010.

Michalakes, J., Dudhia, J., Gill, D., Henderson, T., Klemp, J., Skamarock, W., and Wang, W.: The Weather Research and Forecast model: software architecture and performance, in: To Appear in Proceeding of the Eleventh ECMWF Workshop on the Use of High Performance Computing in Meteorology, edited by: Mozdzynski, E. G., 25-29 October 2004, Reading, UK, 117-124, 2004.

Moussiopoulos, N., Papalexiou, S., Lammel, G., and Arvanitis, T.: Simulation of nitrous acid

\section{Different nitrous acid sources in the air quality levels}

M. Gonçalves et al.

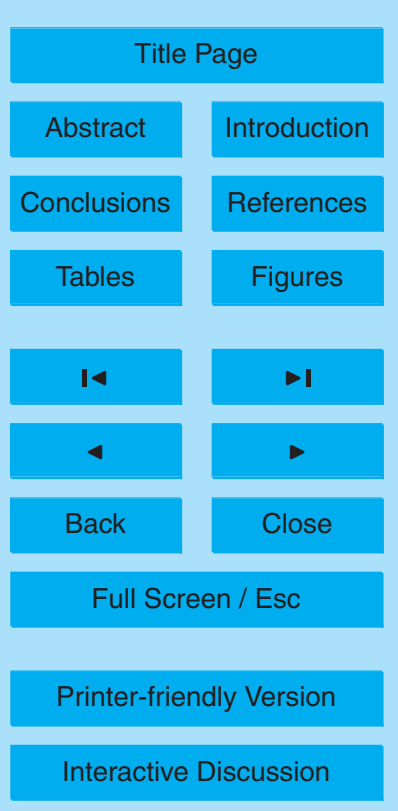


formation taking into account heterogeneous pathways: application to the Milan metropolitan area, Environ. Modell. Softw., 15, 629-637, 2000.

Pay, M. T., Piot, M., Jiménez-Guerrero, P., Jorba, O., Perez, C., and Baldasano, J. M.: Evaluation of the chemically speciated particulate matter from a high-resolution air quality modeling

$5 \quad$ system over the Iberian Peninsula, Geophys. Res. Abs., 11, EGU2009-12179, 2009.

Pay, M. T., Piot, M., Jorba, O., Gassó, S., Gonçalves, M., Basart, S., Dabdub, D., JiménezGuerrero, P., and Baldasano, J. M.: A full year evaluation of the CALIOPE-EU air quality modelling system over Europe for 2004, Atmos. Environ., 44, 3322-3342, 2010.

Piot, M., Pay, M. T., Jorba, O., Jiménez-Guerrero, P., López, E., Gassó, S., and Baldasano, J. M.: Annual dynamics and statistical evaluation of an air quality forecasting system (CALIOPE) with high resolution for Europe, 30th NATO/CCMS International Technical Meeting on Air Pollution Modelling and its Application, San Francisco (USA), 18-22 May 2009.

Platt, U., Perner, D., and Harris, G. W., Winer, A. M., and Pitts, J. N.: Observations of nitrous acid in an urban atmosphere by differential optical absorption, Nature, 285, 312-314, 1980.

Ren, X., Harder, H., Martinez, M., Lesher, R. L., Oliger, A., Shirley, T., Adams, J., Simpas, J. B., and Brune, W. H.: HOx concentrations and $\mathrm{OH}$ reactivity observations during the PMTACSNY 2001 campaign in New York City, Atmos. Environ., 37, 3627-3637, 2003.

Ren, X., Brune, W. H., Mao, J., Mitchell, M. J., Lesher, R. L., Simpas, J. B., Metcalf, A. R., Schwab, J. J., Li, Y., Demerjian, K. L., Felton, H. D., Boynton, G., Adams, A. Perry, J., He, Y., Zhou, X., and Hao, J.: Behaviour of $\mathrm{OH}$ and $\mathrm{HO} 2$ in the winter atmosphere in New York City, Atmos. Environ., 40(2), 252-263, 2006.

Sander, S. P., Finlayson-Pitts, B. J., Friedl, R. R., Golden, D. M., Huie, R. E., Keller-Rudek, H., Kolb, C. E., Kurylo, M. J., Molina, M. J., Moortgat, G. K., Orkin, V. L., Ravishankara, A. R., and Wine, P. H.: Chemical Kinetics and Photochemical Data for Use in Atmospheric Studies, Evaluation Number 15, JPL Publication 06-2, Jet Propulsion Laboratory, Pasadena, 2006.

Sander, S. P., Finlayson-Pitts, B. J., Friedl, R. R., Golden, D. M., Huie, R. E., Kolb, C. E., Kurylo, M. J., Molina, M. J., Moortgat, G. K., Orkin, V. L., and Ravishankara, A. R.: Chemical Kinetics and Photochemical Data for use in Atmospheric Studies, Evaluation Number 14, JPL Publication 02-25, Jet Propulsion Laboratory, Pasadena, 2002.

30 Sarwar, S., Roselle, S., Mathun, R., Appel, W., Dennis, R. L., and Vogel, B.: A comparison of CMAQ HONO predictions with observations from the Northeast Oxidant and Particle Study, Atmos. Environ., 42, 5760-5770, 2008.

Skamarock, W. C. and Klemp, J. B.: A time-split nonhydrostatic atmospheric model for 
weather research and forecasting applications, J. Comput. Phys., 227(7), 3465-3485, doi:10.1016/j.jcp.2007.01.037, 2008.

Sörgel, M., Beyg, Z. H., Regelin, E., Bozem, H., Adame, J. A., Harder, H., Martinez-Harder, M., Held, A., and Zetzsch, C.: What determines the HONO daytime source? First results 5 from field measurements in south west Spain, Geophys. Res. Abs., 12, EGU2010-13137-1, 2010.

Stutz, J., Alicke, B., Ackermann, R., Geyer, A., Wang, S., White, A. B., Williams, E. J., Spicer, C. W., and Fast, J. D.: Relative humidity dependence of HONO chemistry in urban areas, J. Geophys. Res., 109, D03307, doi:10.1029/2003JD004135, 2004.

10 Svensson, R., Ljunstrom, E., and Lindqvjst, O.: Kinetics of the reaction between nitrogen dioxide and water vapour, Atmos. Environ., 21, 1529-1539, 1987.

Syomin, D. A. and Finlayson-Pitts, B. J.: HONO decomposition on borosilicate glass surfaces: implications for environmental chamber studies and field experiments, Phys. Chem. Chem. Phys., 5, 5236-5242, 2003.

US-EPA: Guideline for Regulatory Application of the Urban Airshed Model, Technical Report, EPA-450/4-91-013, U.S. Environmental Protection Agency, Office of Air Quality Planning and Standards, Research Triangle Park, North Carolina, 1991.

US-EPA: Emissions Modeling Clearinghouse Speciation, available at: http://www.epa.gov/ ttnchie1/emch/speciation/, 2003.

20 US-EPA: Guidance on the Use of Models and Other Analyses for Demonstrating Attainment of Air Quality Goals for Ozone, PM2.5, and Regional Haze, Technical Report, EPA-454/B-07002, U.S. Environmental Protection Agency, Office of Air Quality Planning and Standards, Research Triangle Park, North Carolina, 2007.

US-EPA: SPECIATEv4.2, Software developed by US-EPA, available at: http://projects.pechan. $\mathrm{com} / \mathrm{ttn} / \mathrm{speciate} 4.2 .1,2008$.

Vogel, B., Vogel, H., Kleffmann, J., and Kurtenbach, R.: Measured and simulated vertical profiles of nitrous acid. Part II. Model simulations and indications for a photolytic source, Atmos. Environ., 37, 2957-2966, 2003.

Wennberg, P. O. and Dabdub, D.: Rethinking ozone production, Science, 319, 1624-1625, 302008.

Wentzell, J. J. B., Schiller, C. L., and Harris, G. W.: Measurements of HONO during BAQS-Met, Atmos. Chem. Phys. Discuss., 10, 15295-15323, doi:10.5194/acpd-10-15295-2010, 2010.

Winer, A. M. and Biermann, H. W.: Long pathlength differential optical absorption spectroscopy

\section{Different nitrous acid sources in the air quality levels}

M. Gonçalves et al.

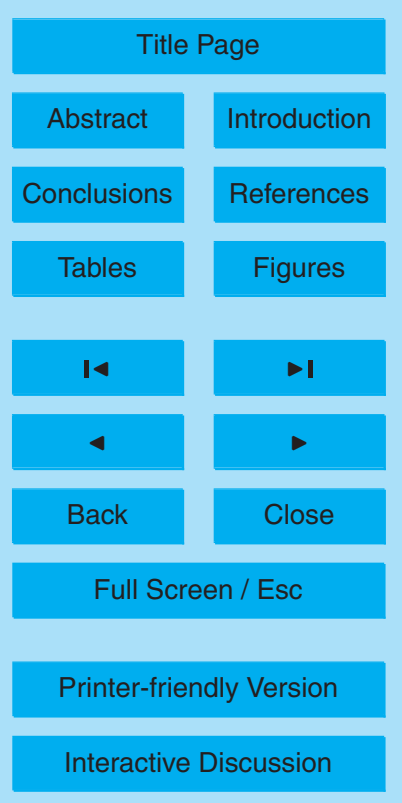


(DOAS) measurements of gaseous $\mathrm{HONO}, \mathrm{NO} 2$ and $\mathrm{HCHO}$ in the California South Coast Air Basin, Res. Chem. Intermed., 20, 423-445, 1994.

Yarwood, G., Rao, S., Yocke, M., and Whitten, G. Z.: Updates to the Carbon Bond Chemical Mechanism: CB05, Final report no. RT-04-00675 prepared for US-EPA on 8 December, 2005.

Zhang, K., Knipping, E., Wexler, A., Bhave, P., and Tonnesen, G.: Size distribution of sea-salt emissions as a function of relative humidity, Atmos. Environ., 39, 3373-3379, 2005.

Ziemba, L. D., Dibb, J. E., Griffin, R. J., Anderson, C. H., Whitlow, S. I., Lefer, B. L., Rappenglu, B., and Flynn, J.: Heterogeneous conversion of nitric acid to nitrous acid on the surface of primary organic aerosol in an urban atmosphere, Atmos. Environ., 44, 4081-4089, 2009.

Different nitrous acid sources in the air quality levels

M. Gonçalves et al.

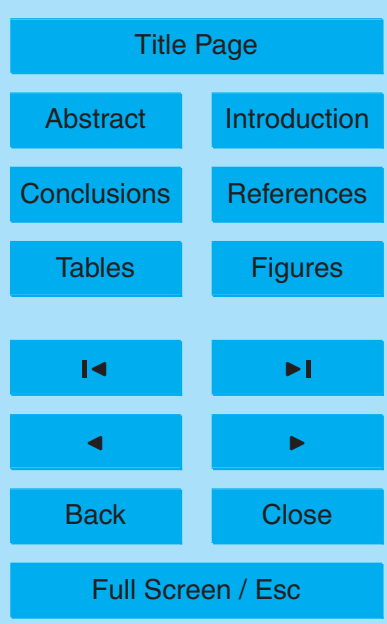

Printer-friendly Version

Interactive Discussion 
Table 1. Chemical reactions and kinetics involving HONO in different chemical mechanisms currently used for air quality modeling.

\begin{tabular}{|c|c|c|c|}
\hline $\begin{array}{l}\text { CB05 (Yarwood et al., 2005) } \\
\text { CBIV (Gery et al., 1988) }\end{array}$ & $\begin{array}{l}\text { SAPRC-07 (Carter, 2010) } \\
\text { SAPRC-99 (Carter, 2000) }\end{array}$ & CACM (Griffin et al., 2002) & $\begin{array}{l}\text { MELCHIOR (Lattuati, 1997), } \\
\text { MELCHIOR2 (Derognat et al., 2003) }\end{array}$ \\
\hline $\begin{array}{l}\mathrm{NO}+\mathrm{OH} \rightarrow \mathrm{HONO} \\
k_{2}=\frac{k_{0}[M]}{\left(1+k_{0}\left[\frac{[M}{k_{1}}\right)\right.} \cdot 0.6\left(1+\left(\log \left(k_{0} \frac{[M]}{k_{1}}\right)\right)^{2}\right)^{-1} \\
k_{0}(\mathrm{CBO5})=7 \times 10^{-31}\left(\frac{T}{300}\right)^{-2.6} \\
k_{0}(\mathrm{CBIV})=6.7 \times 10^{-31}\left(\frac{T}{300}\right)^{-3.3} \\
k_{1}(\mathrm{CBO5})=3.6 \times 10^{-11}\left(\frac{T}{300}\right)^{-0.1^{2}} \\
k_{0}(\mathrm{CBIV})=7 \times 10^{-31}\left(\frac{T}{300}\right)^{-2.6}\end{array}$ & $\begin{array}{l}\mathrm{NO}+\mathrm{OH} \rightarrow \mathrm{HONO} \\
k_{2}=\frac{k_{0}[M]}{\left(1+k_{0} \frac{[M]}{k_{1}}\right)} \cdot 0.6\left(1+\left(\log \left(k_{0} \frac{[M]}{k_{1}}\right)\right)^{2}\right)^{-1} \\
k_{0}=7 \times 10^{-31}\left(\frac{T}{300}\right)^{-2.6} \\
k_{1}=3.6 \times 10^{-11}\left(\frac{T}{300}\right)^{-0.1^{2}}\end{array}$ & $\begin{array}{l}\mathrm{NO}+\mathrm{OH}+\mathrm{M} \rightarrow \mathrm{HONO}+\mathrm{M} \\
k_{2}=\frac{k_{0}[M]}{\left(1+k_{0} \frac{[M]}{k_{1}}\right)} \cdot 0.6\left(1+\left(\log \left(k_{0} \frac{[M]}{k_{1}}\right)\right)^{2}\right)^{-1} \\
k_{0}=7 \times 10^{-31}\left(\frac{T}{300}\right)^{-2.6} \\
k_{1}=3.6 \times 10^{-11}\left(\frac{T}{300}\right)^{-0.1}\end{array}$ & $\begin{array}{l}\mathrm{NO}+\mathrm{OH}+\mathrm{M} \rightarrow \mathrm{HONO}+\mathrm{M} \\
k_{2}=\frac{k_{0}[M]}{\left(1+k_{0} \frac{[M}{k_{1}}\right)} \cdot 0.6\left(1+\left(\log \left(k_{0} \frac{[M]}{k_{1}}\right)\right)^{2}\right)^{-1} \\
k_{0}=7 \times 10^{-31}\left(\frac{T}{300}\right)^{-2.6} \\
k_{1}=3.6 \times 10^{-11}\left(\frac{T}{300}\right)^{-0.1^{8}}\end{array}$ \\
\hline $\begin{array}{l}\mathrm{HONO}+h v \rightarrow \mathrm{NO}+\mathrm{OH} \\
\text { CBO5 }-1.0 /<\mathrm{HONO} \text { IUPACO } 4>/ J=0.002 \\
\mathrm{~s}^{-1^{3}} \\
\text { CBIV - Tabulated: } 0.1975 /<\mathrm{NO}_{2} \text { CBIV88 }>\end{array}$ & $\begin{array}{l}\mathrm{HONO}+h v \rightarrow \mathrm{NO}+\mathrm{OH} \\
\text { SAPRC07: } J \text { tabulated in Carter, } 2010 \\
\text { - Table A3 } 3^{6} \\
\text { SAPRC99: } J \text { tabulated in Carter, } 2000 \\
\text { - Table A2 }\end{array}$ & $\begin{array}{l}\mathrm{HONO}+h v \rightarrow 0.9 \mathrm{NO}+0.1 \quad \mathrm{NO}_{2}+0.9 \\
\mathrm{OH}+0.1 \mathrm{HO}_{2} \\
J=0.0013 \mathrm{~s}^{-1}\end{array}$ & $\mathrm{HONO}+h v \rightarrow \mathrm{NO}+\mathrm{OH}^{9}$ \\
\hline $\begin{array}{l}\mathrm{HONO}+\mathrm{OH} \rightarrow \mathrm{NO}_{2}+\mathrm{H}_{2} \mathrm{O} \\
k_{3}(\mathrm{CBO})=1.8 \times 10^{-11} \cdot \exp \left(\frac{-390}{T}\right)^{2} \\
k_{3}(\mathrm{CBIV})=6.6 \times 10^{-12}\end{array}$ & $\begin{array}{l}\mathrm{HONO}+\mathrm{OH} \rightarrow \mathrm{NO}_{2}+\mathrm{H}_{2} \mathrm{O} \\
k_{3}(\mathrm{SAPRC07})=5.95 \times 10^{-12} . \\
\left(\frac{T}{300}\right)^{-0.52} \exp \left(\frac{-1.25 \times 10^{-9}}{T}\right)^{7} \\
k_{3}(\mathrm{SAPRC} 99)=2.7 \times 10^{-12} \cdot \exp \left(\frac{-260}{T}\right)\end{array}$ & $\begin{array}{l}\mathrm{HONO}+\mathrm{OH} \rightarrow \mathrm{NO}_{2}+\mathrm{H}_{2} \mathrm{O} \\
k_{3}=2.7 \times 10^{-12} \\
\cdot \exp \left(\frac{-261.7}{T}\right)\end{array}$ & $\begin{array}{l}\mathrm{HONO}+\mathrm{OH} \rightarrow \mathrm{NO}_{2}+\mathrm{H}_{2} \mathrm{O} \\
k_{3}=1.8 \times 10^{-11} \cdot \exp \left(\frac{-390}{T}\right)^{8}\end{array}$ \\
\hline
\end{tabular}

${ }^{1}$ Kaiser and Wu, 1997; ${ }^{2}$ Sander et al., 2002; ${ }^{3}$ IUPAC, 2005; ${ }^{4}$ Jeffries et al., 2002; ${ }^{5}$ Bejan et al (2006). XC: lost carbon or carbon unreactive species. Table A-3 in Carter 2010 Phot Set $=\mathrm{NO}_{2}-06$, qy $=1.5 \mathrm{e}^{-3} ;{ }^{6}$ IUPAC, $2006 ;{ }^{7}$ Sander et al., 2006; ${ }^{8}$ Atkinson et al, 1997; ${ }^{9}$ DeMoore et al., 1997.

Units of rate constants are in $\mathrm{cm}^{3} \mathrm{molec}^{-1} \mathrm{~s}^{-1}$.

$T$ : temperature in $\mathrm{K} ; M$ : total pressure in molec $\mathrm{cm}^{-3} ; \mathrm{J}$ : photolysis rate at a latitude of $40^{\circ} \mathrm{N}$ (typical summer noon).

\section{Different nitrous acid sources in the air quality levels}

M. Gonçalves et al.

Title Page

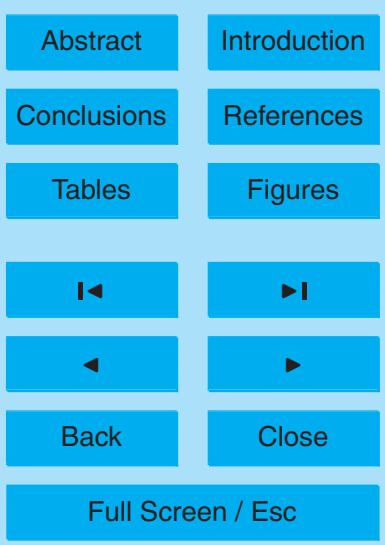

Printer-friendly Version

Interactive Discussion 
Table 2. Scenarios with varying emissions and heterogeneous chemistry sources for HONO production considered in this study.

\begin{tabular}{lllll}
\hline Case & Identifier & HONO emissions & \multicolumn{2}{l}{$\mathrm{NO}_{2}$ hydrolysis on various surfaces (ReactionR6) } \\
\cline { 3 - 5 } & & & Aerosols & Ground \\
\hline 1 & BASENA & None & No & No \\
2 & BASE & None & Yes & No \\
3 & EM08 & $0.8 \%$ of $\mathrm{NO}_{\mathrm{x}}$ from mobile sources & Yes & No \\
4 & EM08HC47 & $0.8 \%$ of $\mathrm{NO}_{\mathrm{x}}$ from mobile sources & Yes & Yes, $k_{1}$ derived from Eq. (1) \\
5 & EM08HCUCl & $0.8 \%$ of $\mathrm{NO}_{\mathrm{x}}$ from mobile sources & Yes & Yes, $k_{2}$ derived from Eq. (5) \\
6 & EM2 & $2 \%$ of total $\mathrm{NO}_{\mathrm{x}}$ & Yes & No \\
7 & EM2HC47 & $2 \%$ of total $\mathrm{NO}_{\mathrm{x}}$ & Yes & Yes, $k_{1}$ derived from Eq. (1) \\
8 & EM2HCUCl & $2 \%$ of total $\mathrm{NO}_{x}$ & Yes & Yes, $k_{2}$ derived from Eq. (5) \\
\hline
\end{tabular}




\section{Different nitrous acid sources in the air quality levels}

Table 3. Urban HONO levels as measured in different studies.

\begin{tabular}{|c|c|c|c|c|c|c|}
\hline $\begin{array}{l}\text { Urban } \\
\text { area }\end{array}$ & Period & $\begin{array}{l}\text { Maximum HONO } \\
\text { concentration (ppb) }\end{array}$ & $\begin{array}{l}\text { Minimum/ } \\
\text { daytime HONO (ppb) }\end{array}$ & $\begin{array}{l}\text { Measurement } \\
\text { technique }\end{array}$ & $\begin{array}{l}\text { Detection } \\
\text { limit (ppb) }\end{array}$ & Reference \\
\hline Los Angeles & August to September 1979 & $1.1-4.1$ b.s. & BDL & $\begin{array}{l}\text { Long path differential } \\
\text { UV absorption }\end{array}$ & 0.28 & Platt et al., 1980 \\
\hline Long Beach & Fall 1987 & 15.0 b.s. & BDL & $\mathrm{DOAS}^{1}$ & 0.8 & Winer and Biermann, 1994 \\
\hline Milan & May to June 1998 & $4.4 \mathrm{n}$. & 0.14 ave. $d$ & DOAS $^{1}$ & 0.2 & Alicke et al., 2002 \\
\hline Berlin & 12 July to 6 August 1998 & 1.11 b.s. & BDL. & DOAS $^{1}$ & 0.11 & Alicke et al., 2003 \\
\hline New York & $\begin{array}{l}\text { June to August 2001, } \\
\text { January to February } 2004\end{array}$ & $\begin{array}{l}0.7 \text { b.s. } \\
0.6 \text { l.a. }\end{array}$ & $0.3 \mathrm{~m}$. & n.e. & n.e. & $\begin{array}{l}\text { Ren et al.,2003 } \\
\text { Ren et al., } 2006\end{array}$ \\
\hline Karlsruhe & 17 to 18 October 2001 & $\approx 1.1$ e.m. ${ }^{*}$ & 0.21 & LOPAP $^{2}$ & 0.002 & Kleffmann et al., 2003 \\
\hline Rome & May to June 2001 & $2.0 \mathrm{n}$. & $\approx 0.2$ ave. $d$ & DOAS $^{1}$ & 0.078 & Acker et al., 2006 \\
\hline Mexico City & Spring, 2003 & $2.5^{*}$ & $\mathrm{BDL}$ & DOAS $^{1}$ & 0.5 & Volkamer et al., 2007 \\
\hline Santiago de Chile & 8 to 20 March 2005 & 7 e.m. 3.7 ave. $n$. & 1.5 .ave.d. & LOPAP $^{2}$ & 0.003 & Elshorbany et al., 2009 \\
\hline Ontario & 20 June to 20 July 2007 & $0.376 \mathrm{n}$ & 0.061 ave. $d$ & LOPAP $^{2}$ & 0.005 & Wentzell et al., 2010 \\
\hline
\end{tabular}

${ }^{1}$ Differential Optical Absorption Spectroscopy; ${ }^{2}$ Long Path Absorption Photometer; * derived from figure; n.: nighttime; d.: daytime; e.m: early morning; b.s.: before sunrise; m.: midday; ave: average; b.d.I.: below detection limit; n.e.: not specified.

M. Gonçalves et al.

Title Page

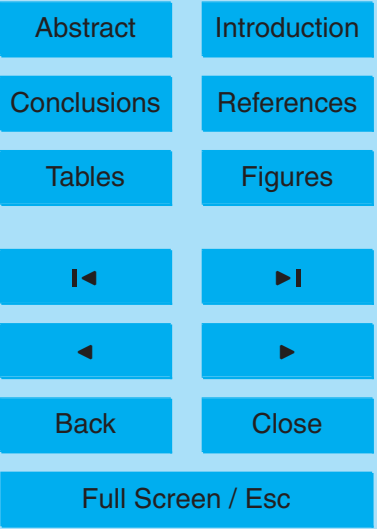

Printer-friendly Version

Interactive Discussion 
Table 4. Quantification of the specific weight of each contribution to the HONO peak concentration for a domain defined over the Madrid urban area $\left(30 \times 30\right.$ cells of $\left.4 \times 4 \mathrm{~km}^{2}\right)$.

\begin{tabular}{lrrrr}
\hline $\begin{array}{l}\text { Estimated contribution (\%) } \\
\text { to peak HONO concentration }\end{array}$ & EM08HCUCl & EM08HC47 & EM2HCUCl & EM2HC47 \\
\hline Gas phase chemistry & & & & \\
Chemistry on aerosol surfaces & 5.2 & 4.0 & 2.0 & 1.8 \\
Emissions & 0.1 & 0.1 & 0.1 & 0.0 \\
Heterogeneous chemistry & 85.3 & 65.5 & 94.3 & 84.3 \\
Peak concentration $(\mathbf{p p b})$ at $\mathbf{0 6 : 0 0}$ UTC & 9.3 & 30.3 & 3.6 & 13.8 \\
\hline
\end{tabular}

ACPD

10, 28183-28230, 2010

Different nitrous acid sources in the air quality levels

M. Gonçalves et al.

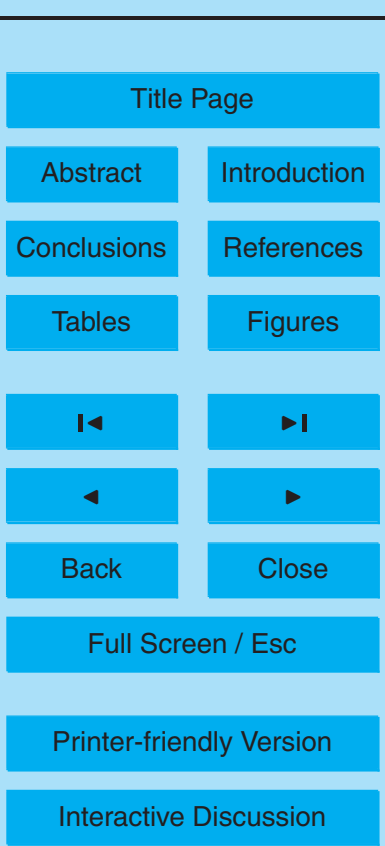




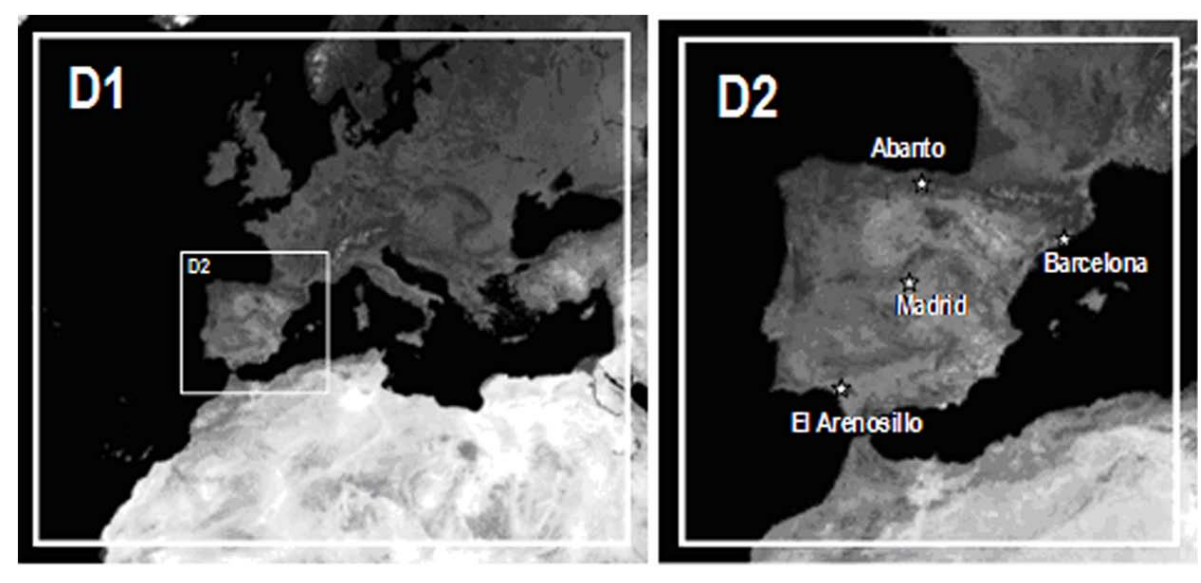

Fig. 1. Defined domains over Europe - D1 - (478 $\times 398$ grid cells at $12 \mathrm{~km}$ horizontal resolution $)$ and the lberian Peninsula - D2 - (397 $\times 397$ grid cells at $4 \mathrm{~km}$ horizontal resolution).

\section{ACPD}

10, 28183-28230, 2010

Different nitrous acid sources in the air quality levels

M. Gonçalves et al.

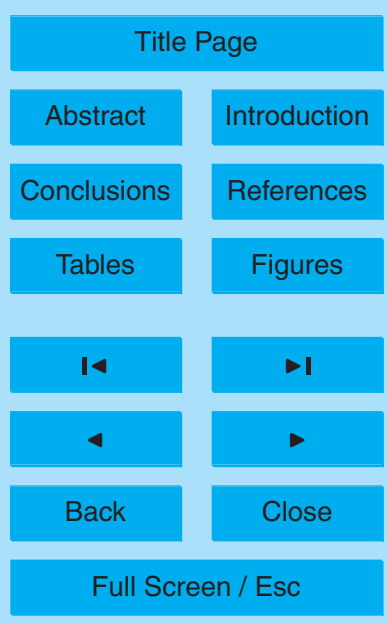

Printer-friendly Version

Interactive Discussion 


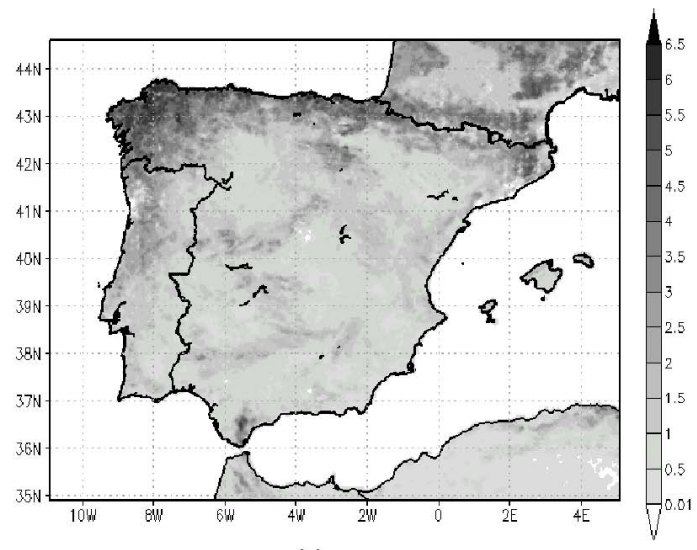

(a)

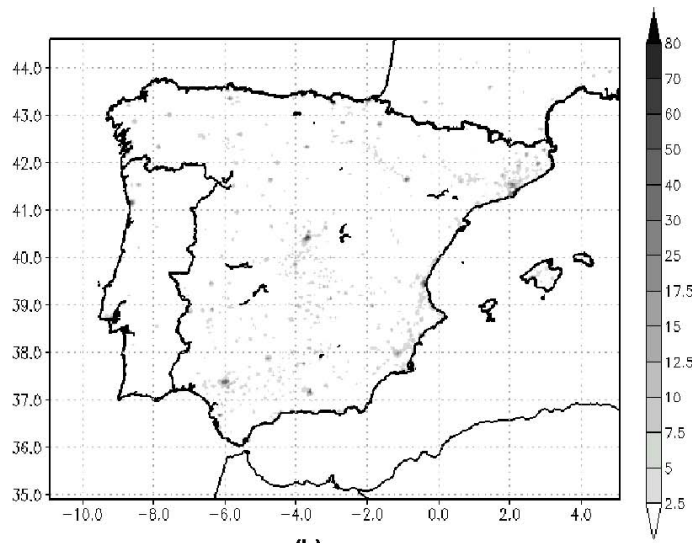

(b)

\section{ACPD}

10, 28183-28230, 2010

Different nitrous acid sources in the air quality levels

M. Gonçalves et al.

\section{Title Page}

Abstract

Introduction

Conclusions

References

Tables

Figures

14

4

Back

\section{Full Screen / Esc}

Printer-friendly Version

Interactive Discussion from the MODIS TERRA MOD15A2 satellite data (June, 2004) and (b) percentage of urban area derived from the CORINE Land Cover Database (2000) IP $4 \times 4 \mathrm{~km}^{2}$ as introduced in the CMAQv4.7 model for the 18 June 2004. 


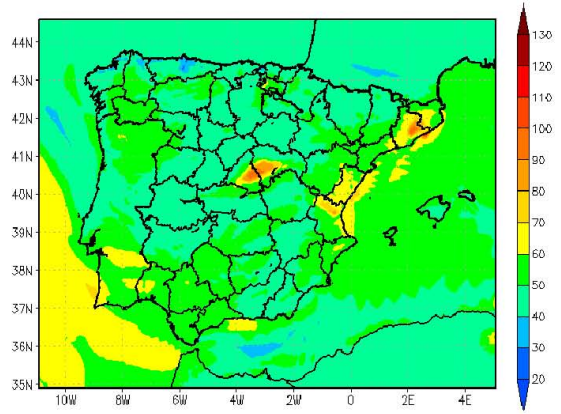

(a)

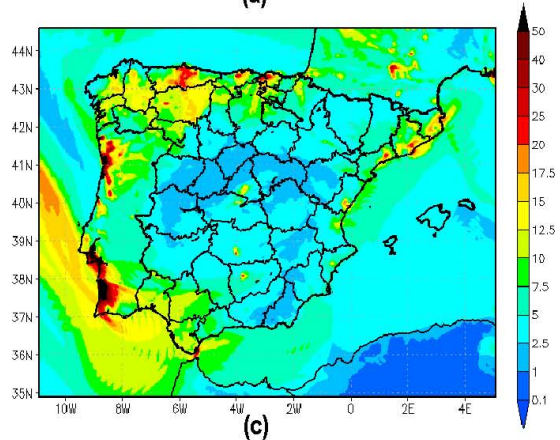

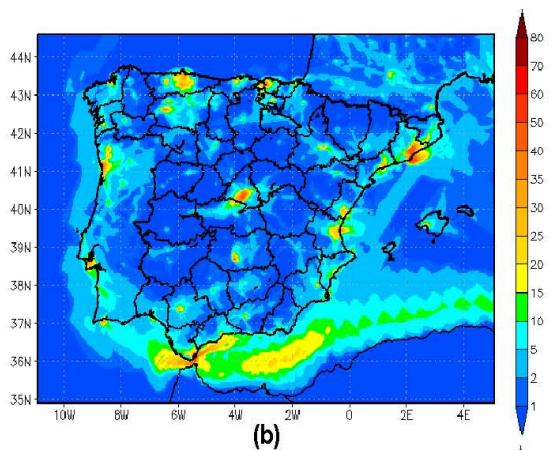

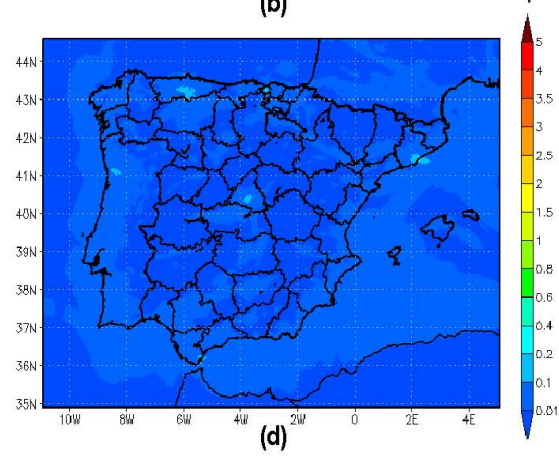

\section{ACPD}

10, 28183-28230, 2010

Different nitrous acid sources in the air quality levels

M. Gonçalves et al.

\section{Title Page}

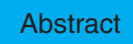

Introduction

Conclusions

References

Tables

Figures

14

4

Back

Close

\section{Full Screen / Esc}

Printer-friendly Version

Interactive Discussion 


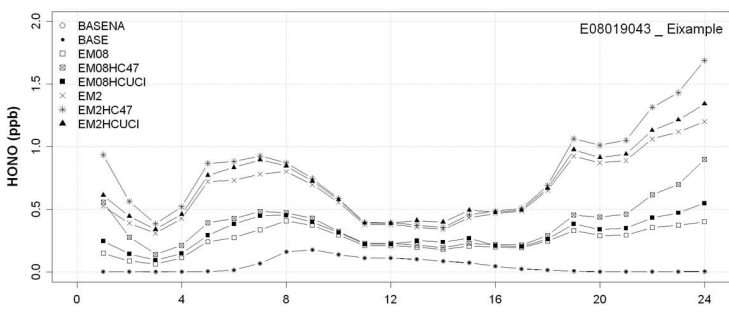

\section{ACPD}

10, 28183-28230, 2010

Different nitrous acid sources in the air quality levels

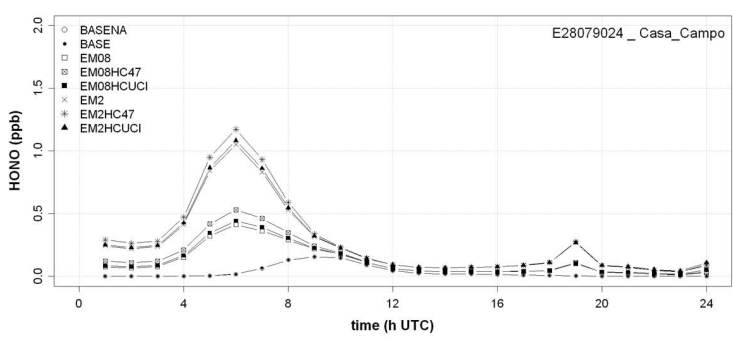

M. Gonçalves et al.

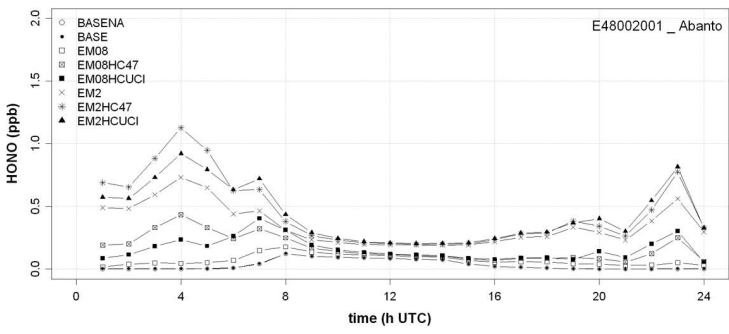

Fig. 4. WRF-ARW/HERMES/CMAQ predicted HONO levels $(\mathrm{ppb})$ at the location of different air quality stations (AQS) in Madrid (Casa de Campo, Background suburban AQS, Lat: $40^{\circ} 24^{\prime} 36^{\prime \prime} \mathrm{N}$; Lon: $3^{\circ} 44^{\prime} 49^{\prime \prime} \mathrm{W}$ ), Barcelona (Barcelona Eixample, Urban traffic AQS. Lat: $41^{\circ} 23^{\prime} 7^{\prime \prime} \mathrm{N}$. Lon: $2^{\circ} 9^{\prime} 14^{\prime \prime} \mathrm{E}$ ) and the northern region of the Iberian Peninsula (Abanto, Suburban industrial AQS, Lat: $43^{\circ} 19^{\prime} 17^{\prime \prime} \mathrm{N}$. Lon: $3^{\circ} 4^{\prime} 22^{\prime \prime} \mathrm{W}$ ) for the BASENA; BASE, EM08, $\mathrm{EM} 08 \mathrm{HC} 47, \mathrm{EM} 08 \mathrm{HCUCl}, \mathrm{EM} 2, \mathrm{EM} 2 \mathrm{HC} 47$ and $\mathrm{EM} 2 \mathrm{HCUCl}$ cases.

Title Page

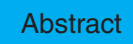

Introduction

Conclusions

References

Tables

Figures

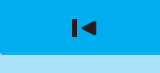

4

Back

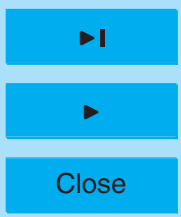

Full Screen / Esc

Printer-friendly Version

Interactive Discussion 


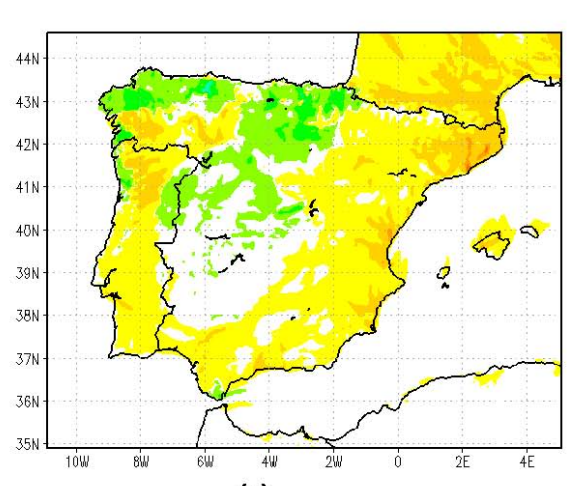

(a)

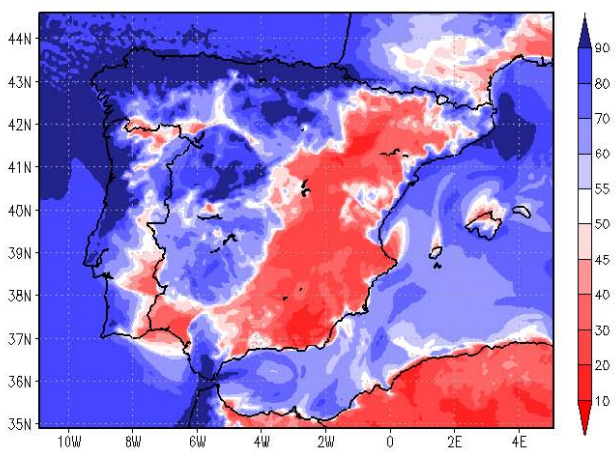

(b)
Fig. 5. (a) Difference in HONO concentration (ppt) for the Iberian Peninsula at 21:00 UTC estimated by the WRF-ARW/HERMES/CMAQ model between the HC47 and the HCUCI cases. Positive values (yellow) involve more efficient HONO production when Eq. (1) is applied to the $\mathrm{NO}_{2}$ hydrolysis kinetics (HC47), negative (green) indicate higher HONO production when using Eq. (5) (HCUCl). (b) Relative humidity (\%) for the Iberian Peninsula at 21:00 UTC estimated by WRF-ARW/HERMES/CMAQ model.
ACPD

10, 28183-28230, 2010

Different nitrous acid sources in the air quality levels

M. Gonçalves et al.

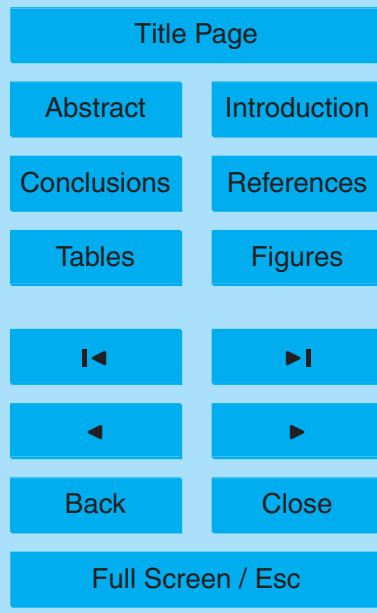

Printer-friendly Version

Interactive Discussion 


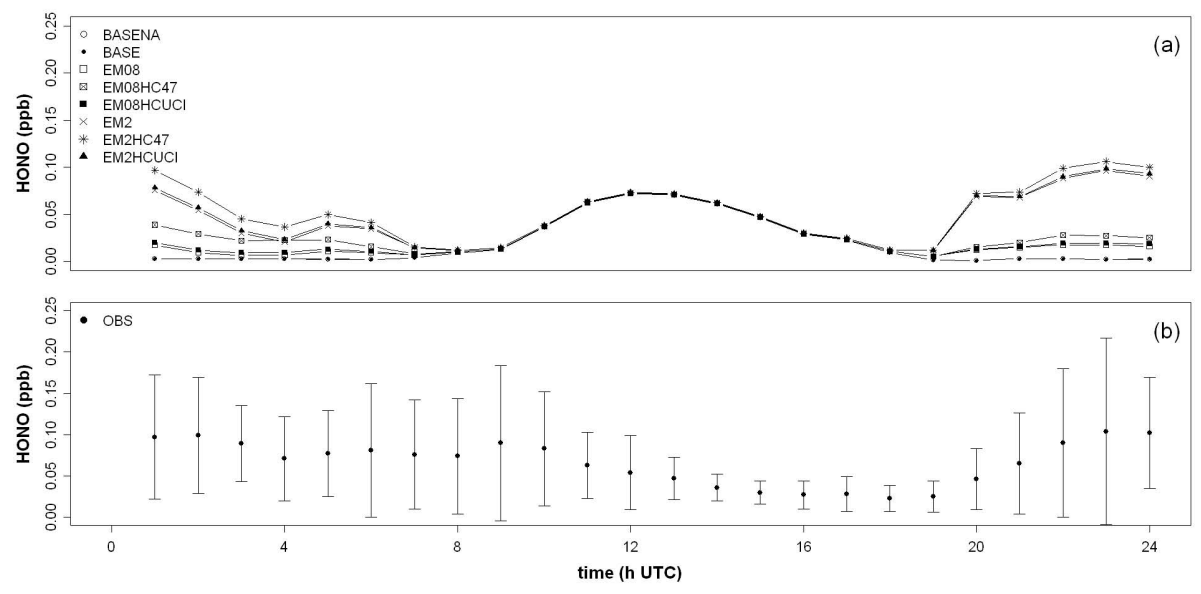

Fig. 6. (a) Modeled HONO levels for the selected episode (18 June 2004) by means of WRFARW/HERMES/CMAQ in the location of the El Arenosillo air quality station. (b) Hourly average and standard deviation of observed HONO levels within the DOMINO campaign (November to December 2008) for the El Arenosillo station (Lat: $37^{\circ} 5^{\prime} 47.89^{\prime \prime} \mathrm{N}$. Lon: $6^{\circ} 44^{\prime} 6.99^{\prime \prime} \mathrm{W}$ ) in the Iberian Peninsula.

\section{ACPD}

10, 28183-28230, 2010

Different nitrous acid sources in the air quality levels

M. Gonçalves et al.

Title Page

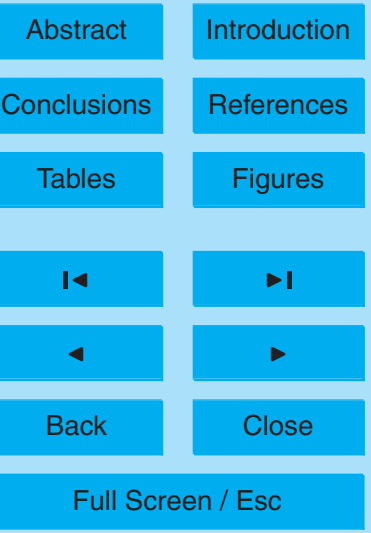

Printer-friendly Version

Interactive Discussion 


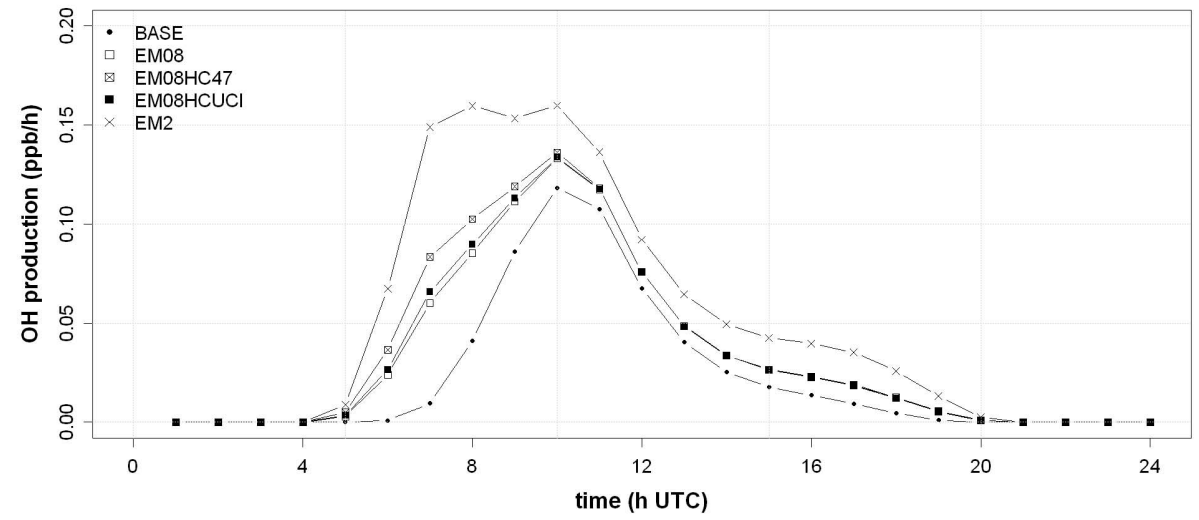

Fig. 7. OH production via HONO photolysis - ppb/h - (Reaction (R3) in CB05 chemical mechanism), in a domain defined over the Madrid urban area $\left(30 \times 30\right.$ cells, $\left.4 \times 4 \mathrm{~km}^{2}\right)$ in the BASE, EM2,EM08_HC47 and EM08_HCUCl cases. As estimated by means of the Integrated Reaction Rate analysis in WRF-ARW/HERMES/CMAQ for the 18 June 2004.

\section{ACPD}

10, 28183-28230, 2010

\section{Different nitrous acid sources in the air quality levels}

M. Gonçalves et al.

Title Page

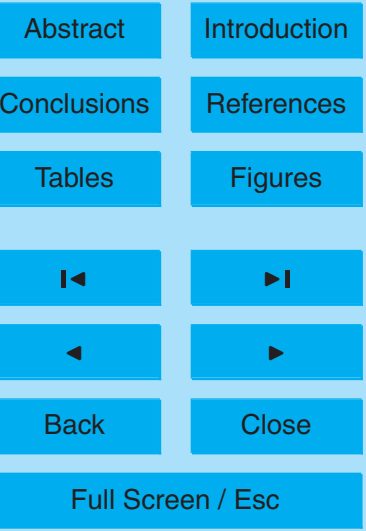

Printer-friendly Version

Interactive Discussion 

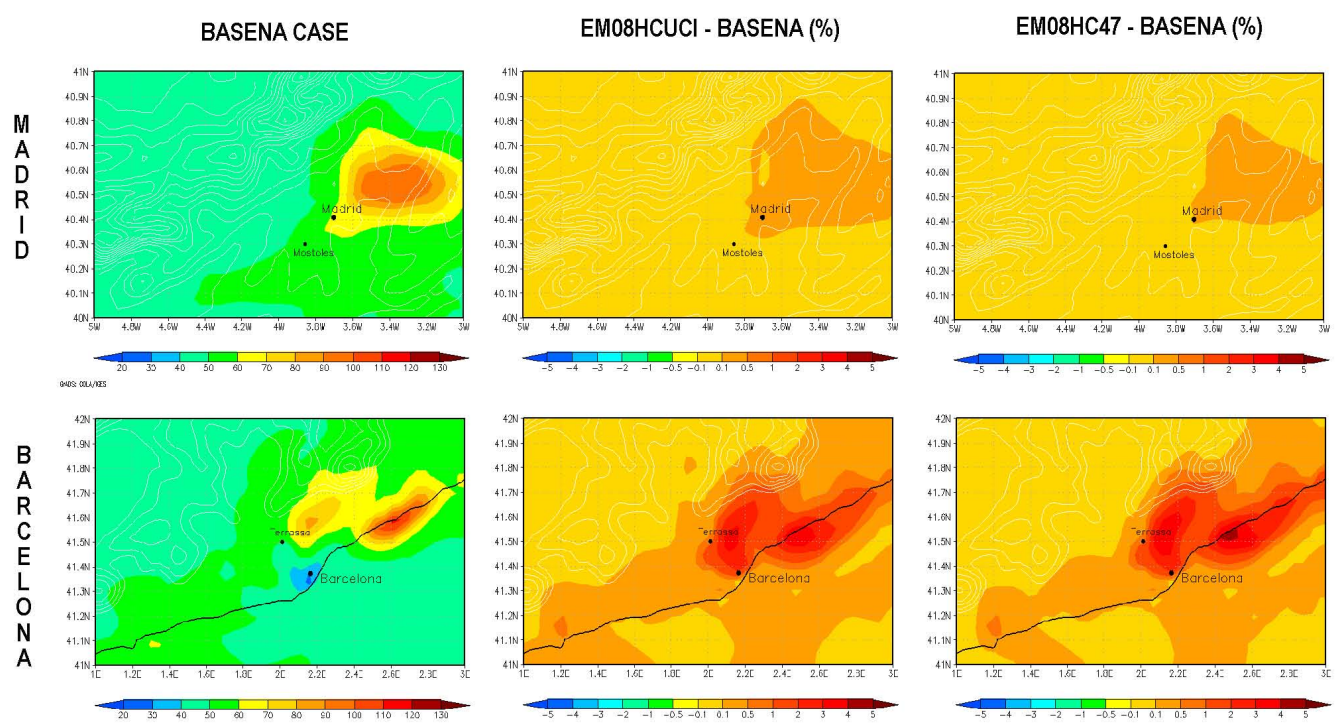

Fig. 8. $\mathrm{O}_{3}$ peak concentration (ppb) in downwind areas from Madrid - at 15:00 UTC - (up) and Barcelona - at 11:00 UTC - (down) as predicted by the WRF-ARW/HERMES/CMAQ model in the BASENA case (left) and \% increase due to the introduction of HONO emissions and heterogeneous chemistry (EM08HCUCl and EM08HC47 cases) (right).

\section{ACPD}

$10,28183-28230,2010$

Different nitrous acid sources in the air quality levels

M. Gonçalves et al.

\section{Title Page}

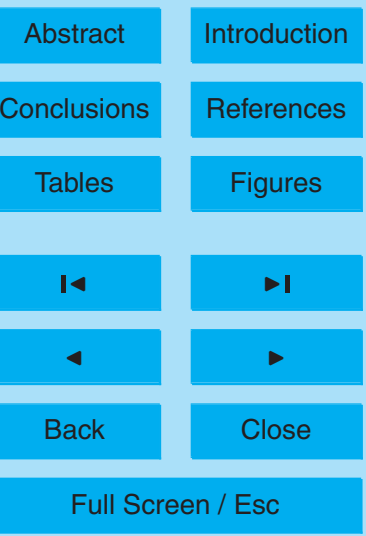

Printer-friendly Version

Interactive Discussion 


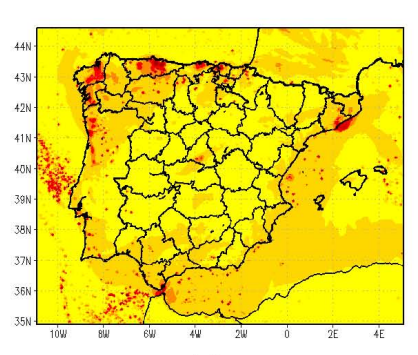

(a)

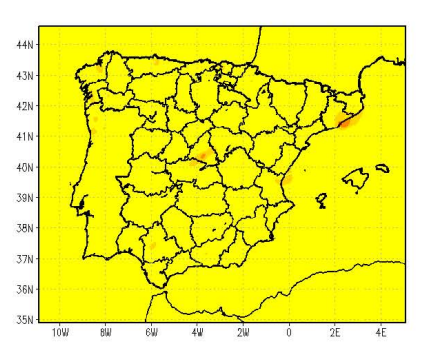

(c)

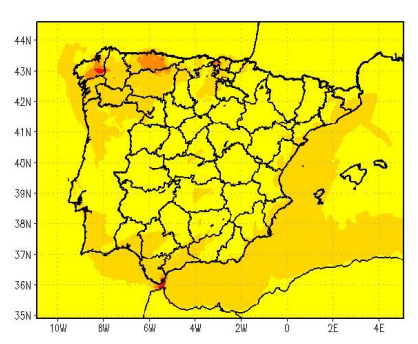

(e)

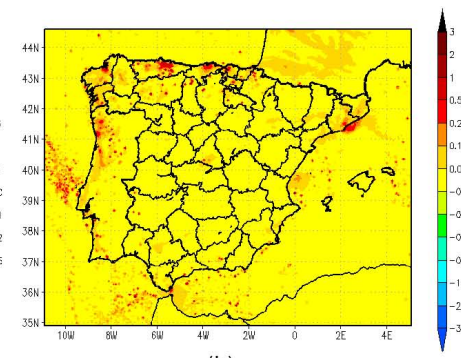

(b)

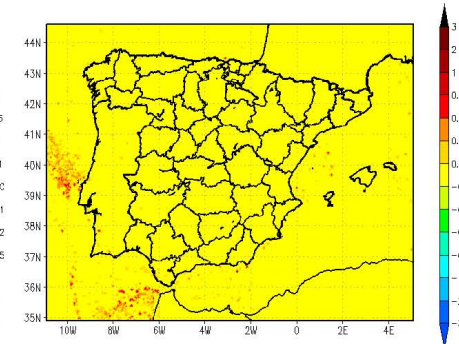

(d)

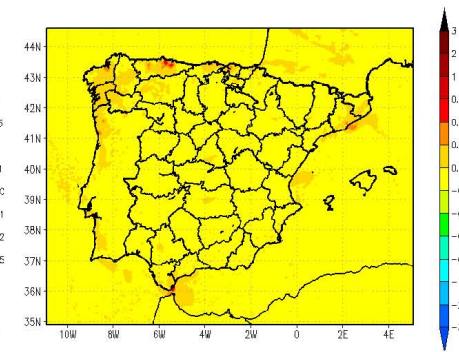

(f)

\section{ACPD}

10, 28183-28230, 2010

Different nitrous acid sources in the air quality levels

M. Gonçalves et al.

Title Page

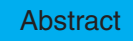

Introduction

Conclusions

References

Tables

Figures

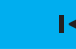

4

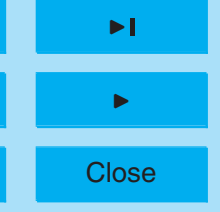

Back

\section{Full Screen / Esc}

Printer-friendly Version

Interactive Discussion

(e) sulfate and (f) ammonia fraction in $\mathrm{PM}_{25}$ in the Iberian Peninsula when introducing the EM08HC47 case respect to the BASENA case during the 18 June 2004; as estimated by WRF-ARW/HERMES/CMAQ. 

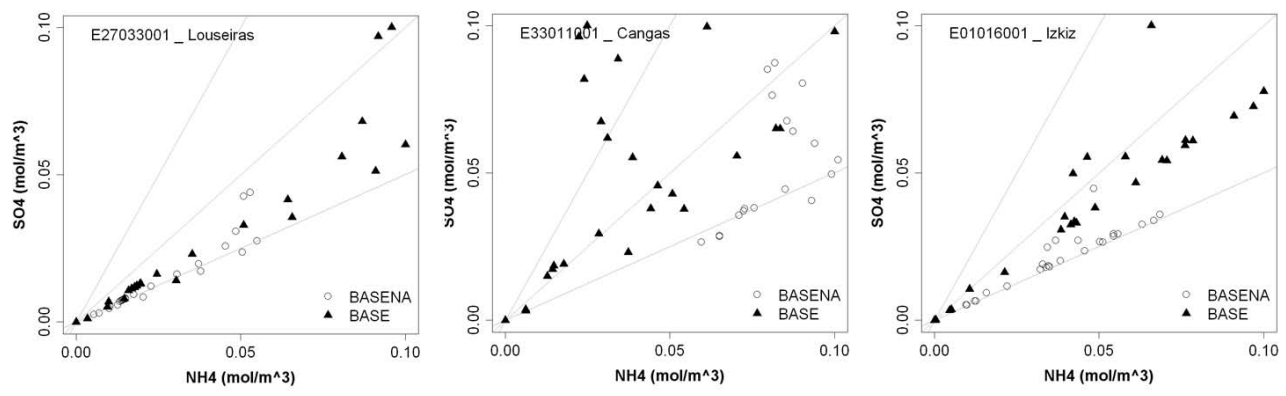

\section{ACPD}

10, 28183-28230, 2010

Different nitrous acid sources in the air quality levels

M. Gonçalves et al.
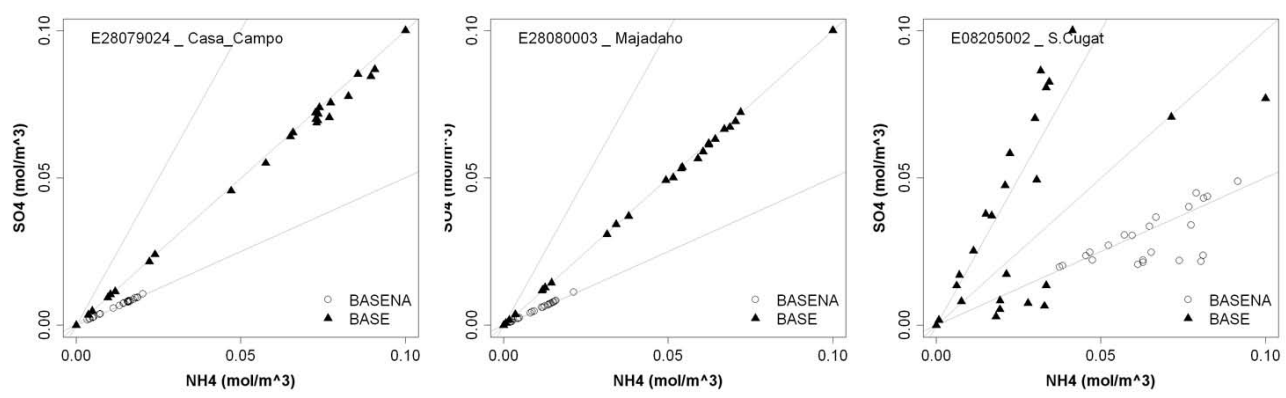

Fig. 10. $\mathrm{SO}_{4}\left(\mathrm{~mol} / \mathrm{m}^{3}\right)$ respect to $\mathrm{NH}_{4}\left(\mathrm{~mol} / \mathrm{m}^{3}\right)$ in the aerosol phase at three different locations in the northern region of the Iberian Peninsula: Louseiras, Cangas and Izkiz (up, from left to right) and three different locations in urban environments: Casa de Campo (Madrid), San Cugat and Majadahonda (down, from left to right), as estimated by WRF-ARW/HERMES/CMAQ for the 18 June 2004 in the BASENA case (circles) and the BASE case (triangles).

Title Page

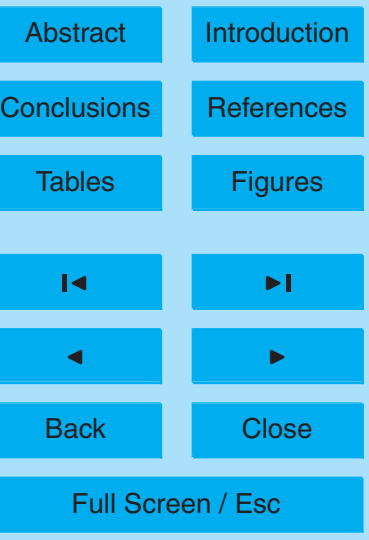

Printer-friendly Version

Interactive Discussion 